\title{
Tephra fallout from the long-lasting Tungurahua eruptive cycle (1999-2014): Variations through eruptive style transition and deposition processes
}

\author{
*Jorge Bustillos A. ${ }^{1}$, Jorge E. Romero², Alicia Guevara C. ${ }^{3}$, Juan Díaz-Alvarado²
}

\author{
I Facultad de Geología Minas, Petróleos y Ambiental, Carrera de Ingeniería en Geología, Universidad Central del Ecuador, casilla \\ 872 A, Quito, Ecuador. \\ jebustillos@uce.edu.ec \\ 2 Departamento de Geología, Universidad de Atacama, Avda. Copayapu 485, Copiapó, Chile. \\ jorge.romerom@alumnos.uda.cl; juan.diaza@uda.cl \\ 3 Departamento de Metalurgia Extractiva, Escuela Politécnica Nacional, Avda. Ladrón de Guevara E11-253 Quito, Ecuador. \\ alicia.guevara@epn.edu.ec \\ *Corresponding author: jebustillos@uce.edu.ec
}

\begin{abstract}
The Tungurahua volcano (Northern Andean Volcanic Zone) has been erupting since 1999, with at least four eruptive phases up to present. Although a dozen of research focuses in tephra fall deposits during this period, none of them cover the full eruptive cycle. We investigated the eruptive mechanisms and tephra fall deposition processes at Tungurahua between 1999 and 2014, through systematic analyses of tephra samples collected westward of the volcano using mechanical sieving grain size analysis, lithology, scanning electron microscopy, X-Ray fluorescence and X-Ray diffraction. Tephra is compounded by varying amounts of scoria (black and brown), lithics, hydrothermally altered fragments, pumice, glass shards and free crystals. Textural analyses of juvenile grains (scoria, pumice and glass shards) revealed a diversity of features concerning to their vesicularity, shape and surface/perimeter. Initially, tephra was characterized by hydrothermally altered fragments related to a phreatic phase which then evolved to a pure magmatic activity with Strombolian eruptions. A homogeneous andesitic composition was observed between 1999 and 2003; however silicarich compositions occurred later in 2006. Similarly, the mineral assemblage contained plagioclase, pyroxene and olivine, but magnetite and akermanite were then included during 2006, thus indicating the eruption of a new, probably mixed magma. As consequence, Plinian activity occurred in August 2006. Further activity in 2007 ejected notable amounts (40$65 \%$ ) of recycled material during Vulcanian eruptions. New eruptions occurred between 2008 and 2010, and juvenile ash revealed the interplay between brittle and ductile fragmentation through ash explosions, jetting events and Strombolian activity. The activity between 2010 and 2012 incorporated hydrothermally altered material at time that eruptive silences became longer and frequent, thus suggesting the development of a sporadic hydrothermal system. Finally, between 2013 and 2014 a series of Vulcanian events occurred. Observed grain size distributions allow us to propose three different processes occurring during tephra deposition: 1) deposition of multiple ash plumes, 2) contributions from elutriated pyroclastic density currents or grain size mixing due to major eruptions, and $\mathbf{3}$ ) the aggregation of particles due to rain and/or lighting. From mineralogy and grain size we infer that exposition to ash may produce acute human health effects.
\end{abstract}

Keywords: Eruptive mechanism, Tephra fall deposits, Andesitic volcanism, Tungurahua volcano.

RESUMEN. Caída de tefra del ciclo eruptivo de larga duración del volcán Tungurahua (1999-2014): variaciones a través de las transiciones de estilo eruptivo y de los procesos depositacionales. El volcán Tungurahua (Zona Volcánica Norte de los Andes) inició, el año 1999, un proceso eruptivo y desde entonces han acontecido al menos cuatro fases eruptivas. Aunque una docena de investigaciones se centran en los depósitos de tefra acumulados durante este período, ninguno de ellos cubre el ciclo eruptivo completo. Se investigaron los mecanismos eruptivos y los procesos de depositación de la tefra entre 1999 y 2014, a través de análisis sistemáticos de muestras de tefra recolectadas al oeste del volcán, utilizando análisis mecánico de granulometría, litología, microscopía electrónica de barrido, fluorescencia de rayos X y difracción de rayos X. La tefra está compuesta por cantidades variables de escoria (negra y marrón), líticos, fragmentos alterados hidrotermalmente y fragmentos de pómez, vidrio y cristales. Los análisis texturales de fragmentos juveniles (escoria, pómez y vidrio) revelaron diversas características en cuanto a su vesicularidad, forma y superficie/perímetro. 
En la etapa inicial del proceso eruptivo, la tefra se caracterizó por la presencia de fragmentos alterados hidrotermalmente relacionados con una fase freática, que luego evolucionó a una actividad magmática con erupciones estrombolianas. La composición química y mineralógica del material juvenil de las tefras indica una composición andesítica homogénea para el magma eyectado entre los años 1999 y 2003; sin embargo, composiciones ricas en sílice se produjeron posteriormente en 2006. De forma similar, el conjunto mineral contenía plagioclasa, piroxeno y olivino, pero se incluyeron magnetita y akermanita durante 2006, indicando un cambio en la composición del magma, probablemente mezclado. Como consecuencia de este cambio, en agosto 2006 ocurrió una erupción pliniana. La actividad eruptiva en el año 2007 arrojó cantidades notables (40-65\%) de material reciclado durante erupciones vulcanianas. Nuevas erupciones ocurridas entre los años 2008 y 2010, y el material juvenil de la ceniza eyectada reveló la interacción entre fragmentación frágil y dúctil a través de explosiones de cenizas, eventos de chorro y actividad estromboliana. La actividad entre los años 2010 y 2012 incorporó material hidrotermalmente alterado durante silencios eruptivos, los que se hicieron más frecuentes y prolongados, sugiriendo así el desarrollo de un sistema hidrotermal esporádico. Finalmente, entre 2013 y 2014 ocurrieron una serie de erupciones Vulcanianas. La distribución de tamaño del grano observada en los depósitos de tefra nos permite proponer tres procesos diferentes que ocurren durante su depositación: 1) depositación múltiple de plumas de ceniza, 2) contribuciones de corrientes de densidad piroclásticas elutriadas o mezclas de granulometría debido a grandes erupciones, y 3) agregación de partículas debido a la lluvia y/o tormentas eléctricas. A partir de la mineralogía y tamaño de grano inferimos que la exposición a la ceniza puede producir efectos agudos en la salud humana.

Palabras clave: Mecanismo eruptivo, Depósitos de caída de tefra, Volcanismo andesítico, Volcán Tungurahua.

\section{Introduction}

Studies of geochemical, mineralogical and lithological properties of tephra fall deposits are currently used as robust analytical tools for the complementary description of eruptive styles and processes (Cioni et al., 2008; Tsunematsu and Bonadonna, 2015). As inherited characteristics from these eruptive processes, the shape and nature of the main constituents of volcanic ash reflect explosive mechanisms of volcanic eruptions, and their transition in time contribute to forecast the changes of ongoing eruptive events (Dellino and Volpe, 1995; Cannata et al., 2014; Clarke et al., 2015; Taddeucci et al., 2015). Besides, determination of tephra grain size distribution (GSD) provide important insights into fragmentation mechanisms, eruptive conditions, tephra deposition and volcanic hazards at active volcanoes (e.g., Walker, 1971; Carey and Sigurdsson, 1982; Bonadonna et al., 2002; Houghton and Carey, 2015). In fact, understanding the eruption mechanisms is critical for improving hazard assessment during volcanic crises. This is especially important at longlasting eruptions for the recognition and mitigation of evolving volcanic hazards through time.

Tungurahua volcano $\left(01^{\circ} 28^{\prime} \mathrm{S} ; 7^{\circ} 27^{\prime} \mathrm{W}\right.$, $5,019 \mathrm{~m}$ a.s.l., Fig. 1) is an active andesitic stratovolcano at the Northern Andean Volcanic Zone (NAVZ; Kley et al., 1999), distant $120 \mathrm{~km}$ south of Quito (Ecuador), with a record of five post-Columbian eruptive cycles (1641, 1773, 1886, 1916-18 and 1999 to the time of writing). Since 1999 and up to 2014,
Tungurahua volcano has erupted $c a .0 .13 \mathrm{~km}^{3}$ of bulk tephra, frequently dispersed towards its west flank, through various types of volcanic activity in four major eruptive phases (Bustillos et al., 2016). Several studies with different techniques have included the analysis of these tephras in very specific time periods such as those of 1999-2001, 2006, 2010, 2012, 2013, and 2014 (e.g., Le Pennec et al., 2004; Ruiz et al., 2004; Troncoso et al., 2006; Bustillos, 2010; Bustillos et al., 2011; Le Pennec et al., 2012; Eychenne et al., 2012; Bustillos et al., 2013; Bernard et al., 2013; Eychenne et al., 2013; Parra et al., 2015; Romero et al., 2017). Currently, there is not a continuous database of tephras between 1999 and 2013 in Tungurahua, doing harder to establish their variations through eruptive-style transitions and their related feeding mechanisms. In the current contribution, we study the temporal variations of tephra fallouts as consequence of changing eruption mechanisms between 1999-2014 at Tungurahua volcano. We also look at the amount of fine ash ejected by the volcano for health hazard considerations. Overall, our work provides a comprehensive dataset on the characteristics of ash erupted by Tungurahua during fifteen years of eruptive activity.

\section{Geological and Volcanological Settings}

\subsection{Geological background}

The volcanoes of the Northern Andean Volcanic Zone are mainly andesitic and dacitic, although 


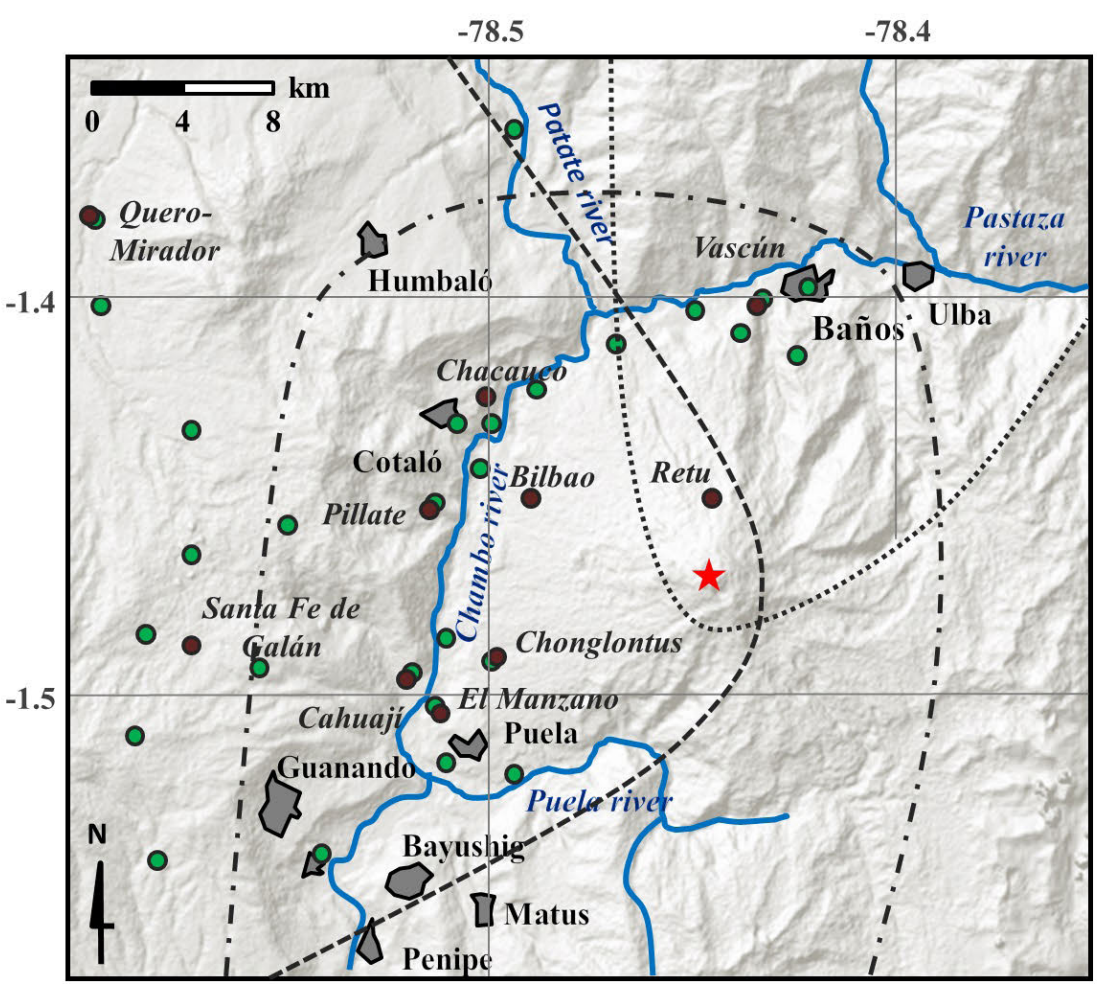

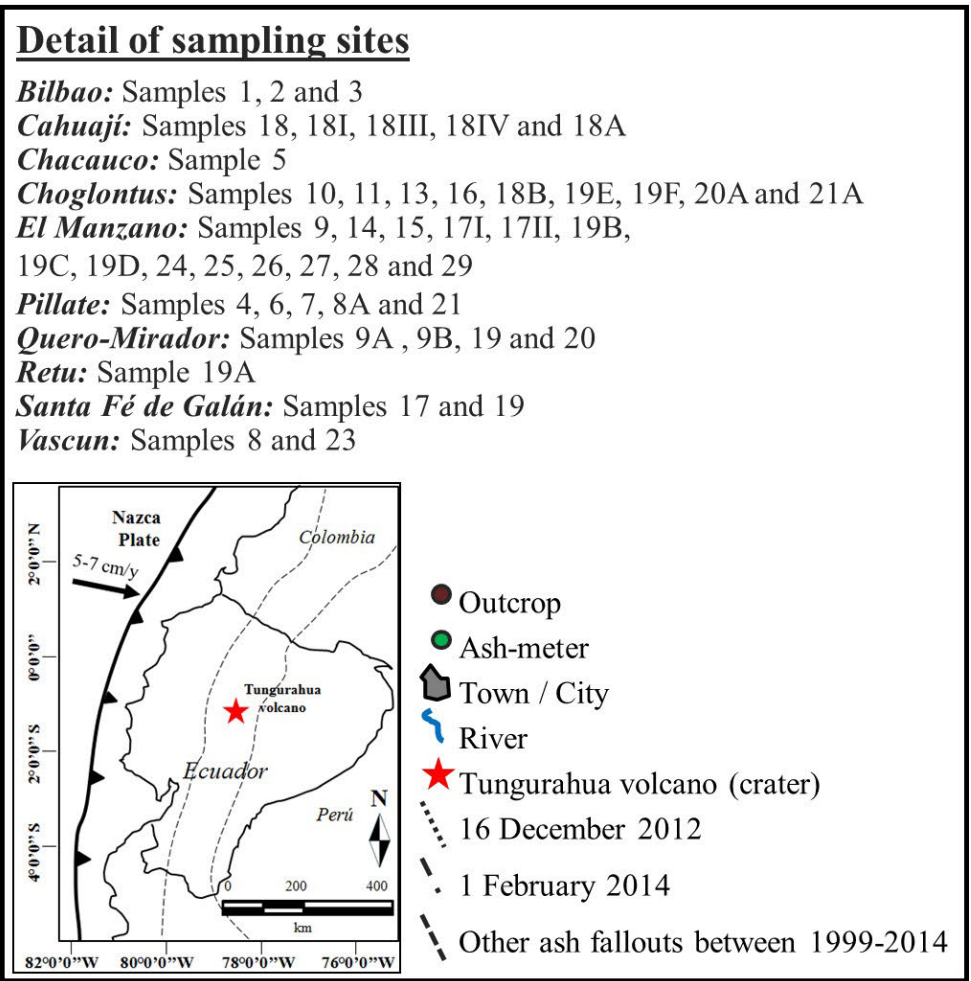

FIG. 1. Location of Tungurahua volcano. The sampling sites in outcrop (brown dots) and the location of ash-meters (green dots) administered by IG-EPN are included in the map. See legend for details on the sampling sites and their correspondent samples. Dispersion of relevant tephra falls are indicated as dashed lines. 
basaltic andesites and rhyolites also occur (Stern, 2004). The Ecuadorian active continental volcanism is distributed in two main chains: Western Cordillera and Eastern Cordillera, but also along the InterAndean valley and in the back-arc position (Hall et al., 2008). The youngest eruptive products at the Eastern Cordillera are low-to high-silica andesites with a typical calc-alkaline affinity $(56-61 \mathrm{wt} \%$ $\mathrm{SiO}_{2}$; Hall et al., 2008). Tungurahua volcano is located at Eastern Cordillera, and it corresponds to an andesitic to dacitic stratovolcano (54-67 wt\% $\mathrm{SiO}_{2}$; Hall et al., 1999), whose edifice elevates $3 \mathrm{~km}$ height above its basement made of Paleozoic to Cretaceous age rocks, locally intruded by granitic plutons of Paleozoic to Jurassic ages (Litherland and Egüez, 1993; Aspden et al., 1994; Le Pennec et al., 2008; Le Pennec et al., 2012). The volcano consists of three edifices (Tungurahua I, II, and III), while two sector collapses are recognized to have occurred $30 \mathrm{ky}$ and $3 \mathrm{ky}$ BP (Hall et al., 1999; Molina et al., 2005; Le Pennec et al., 2006; Bustillos, 2008). The youngest edifice (Tungurahua III) grew inside the last collapse scarp (3 ky BP), on the western flank of the Tungurahua II stratocone (Le Pennec et al., 2008). Since $\sim 700{ }^{14} \mathrm{C}$ yr BP the activity has included pyroclastic density currents (PDCs) and tephra falls, with a period of notable eruptive activity during the $14^{\text {th }}$ century (Le Pennec et al., 2008).

\subsection{Eruptive activity since 1999}

Historical eruptions took place in 1641-1646, 1773-1781, 1886-1888, 1916-1918, leading up to the current eruptive cycle which began in 1999 and persists until the time of writing (Almeida and Ramón, 1991; Hall et al., 1999; Le Pennec et al., 2008). According to Bustillos et al. (2016), Tungurahua volcano has erupted a cumulative tephra volume of $130 \mathrm{Mm}^{3}$ between 1999 and 2014 (about $42 \mathrm{Mm}^{3}$ were erupted only in 2006 eruptions; Eychenne et al., 2012), which in most of cases ( $70 \%)$ has affected its western flank due to the prevailing wind direction in that area (Fig. 1; Le Pennec et al., 2012; Bernard et al., 2013; Parra et al., 2015). In addition, the average non-DRE (Dense Rock Equivalent) tephra deposition rate increased from $\sim 8,700 \mathrm{~m}^{3} /$ day to $\sim 19,000 \mathrm{~m}^{3} /$ day after the 2006 explosive phases (Bustillos et al., 2016). Maps showing actual distributions of fallout and PDC deposits from representative eruptions are available from Eyechenne et al. (2012); Le Pennec et al. (2012); Eychenne et al. (2013), Bernard et al. (2013), Bernard et al. (2016) and Bustillos et al. 2016. The current eruptive cycle has experienced four phases between 1999 and 2013 (Bustillos et al., 2016) (Fig. 2).

\subsubsection{Phase I (1999-2005)}

The reawakening of Tungurahua was progressive between August and October 1999, with a phreatic vent-clearing onset followed by magmatic activity in mid-October, and then by alternating phases of gas and ash emissions, Strombolian to violent Strombolian eruptions and many canon-like shots associated with short-lived "Vulcanian-like" explosions (Ruiz et al., 2006; Le Pennec et al., 2012). After seven months of quiescence, deep LP seismicity announced a new eruption beginning in late May 2001, which developed small-scale lava fountains and explosions in June and July (Le Pennec et al., 2002). Prior to the August $4^{\text {th }}$ 2001 eruption, precursory activity was not recorded and surface phenomena consisted of Strombolian to violent Strombolian activity, including a lava fountaining event by August $16^{\text {th }}$ before the waning of eruption in August 21 $1^{\text {st }}$ (Le Pennec et al., 2012). New activity dominated by Strombolian phases produced sub-regional to regional ash falls that persisted until 2005 (Mothes et al., 2015). Samaniego et al. (2011) proposed that episodic injections fed magma to a modest reservoir $10 \mathrm{~km}$ bellow Tungurahua's crater, which in turn supplied magma to the surface between 1999 and 2005. However, Wright et al. (2012) concluded that variable magma supply rates better explain the transition between Vulcanian and Strombolian styles through an almost persistent eruptive activity.

\subsubsection{Phase II (July-August 2006)}

Precursory signals as deep long-lasting seismic activity (5-15 km below the summit) in early April 2006 and edifice deformation consistent with the intrusion of $4.5 \mathrm{Mm}^{3}$ of magma were registered between March $10^{\text {th }}$ and April 14 2006 (Champenois et al., 2014). The intrusion of a new, hot and volatile-rich magma batch probably disrupted the more evolved and degassed magma reservoir of Tungurahua, leading to the dramatic Plinian eruptions of 2006 (e.g., Samaniego et al., 2011; Eychenne et al., 2013; Myers et al., 2014). The first eruption took place on July $14^{\text {th }}$, with a $10 \mathrm{~km}$-high (above the crater) tephra column and several scoria flows that descended by 


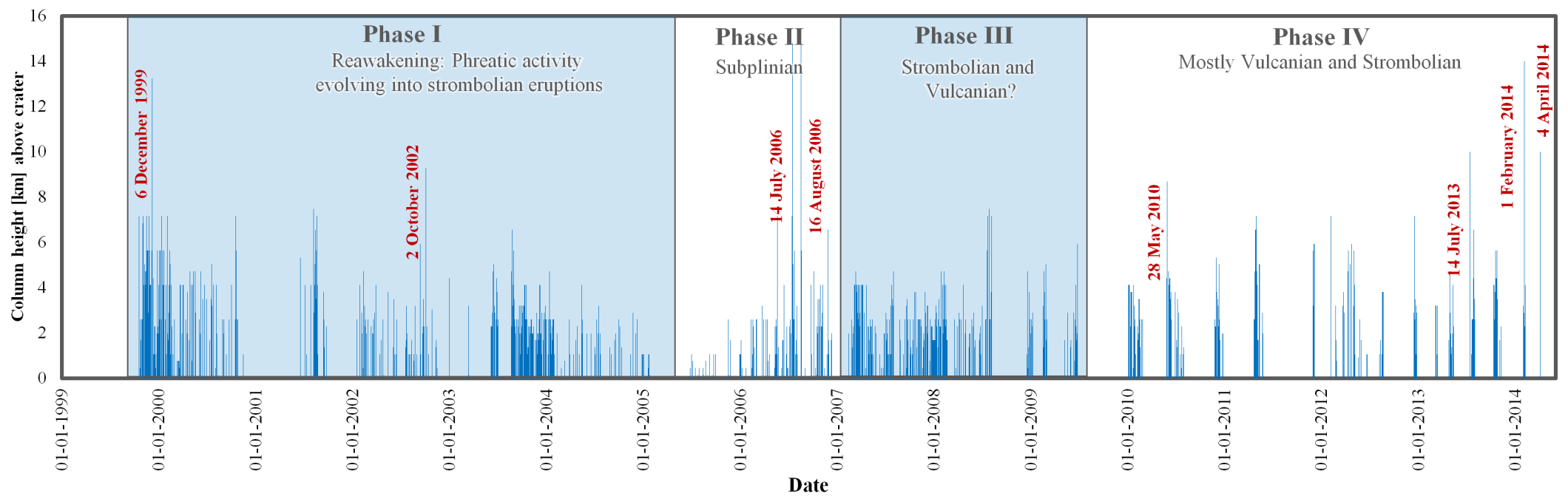

FIG. 2. Eruptive phases during the 1999-2014 eruptive cycle at Tungurahua volcano as defined by Bustillos et al. (2016) combining direct observation, available data published for each eruption (see references therein), and column heights (km above the crater). 
the western flank of the cone. The second eruption occurred after a rapid increase of seismic activity in the morning of August $16^{\text {th }}$, and consisted of a sustained eruption that started at 22:00 $\mathrm{h}$ UTC leading to a paroxysmal phase about $05: 15 \mathrm{~h}$ UTC on August $17^{\text {th }}$ and lasted around 50-60 min. (Eyechenne et al., 2013). The July $14^{\text {th }}$ eruption ejected about $1.0 \mathrm{Mm}^{3}$ of dense rock equivalent (DRE) products, while the August $16-17^{\text {th }}$ eruptions produced a stratospheric column ( $\sim 14 \mathrm{~km}$ above the crater) with the ejection of $c a .7 .7 \mathrm{Mm}^{3}$ of DRE juvenile tephra and a $18.7 \mathrm{Mm}^{3}$ of DRE PDCs (Steffke et al., 2010; Eyechenne et al., 2012, 2013; Hall et al., 2013; Douillet et al., 2013a, 2013b). Eychenne et al. (2013) estimated both the July $14^{\text {th }}$ and August $16-17^{\text {th }}$ eruptions to be of volcanic explosivity index (VEI) values of 2 and 3 , from ground based data.

\subsubsection{Phase III (2007-2009)}

Beginning in August 2007, heightened seismic activity associated with explosion events and jetting activity was recorded up to the February 2008 eruption, and even a ground uplift (17.5 $\mathrm{cm}$ in vertical axis) originated in the upper western flank was visible in interferograms that span the period December $26^{\text {th }}$ 2007 to March $27^{\text {th }} 2008$, probably triggered by a magma intrusion of $1.2 \mathrm{Mm}^{3}$ (Biggs et al., 2010). Following the February 2008 Vulcanian eruption, the volcano experienced a period of relative quiescence with a few small explosions and jetting tremors recorded (Biggs et al., 2010). Since 2008, short- to medium-lived Strombolian eruptions have occurred, spanning from a few days to a few weeks, separated by periods of quiescence ranging from two to six months (Bernard et al., 2013).

\subsubsection{Phase IV (2010 to the present)}

Since 2010, the activity has been interspersed by Vulcanian eruptions with varying intensity, often accompanied by explosions as well as small PDCs, some of them reaching the volcano's base (Mothes et al., 2015; Hall et al., 2015; Parra et al., 2015; Romero et al., 2017). One of the largest Vulcanian events recorded at Tungurahua during the current eruptive cycle occurred in February $1^{\text {st }}$ 2014, with a minimum erupted volume of about $1.2 \mathrm{Mm}^{3}$ of PDCs and 4.5-6.4 $\mathrm{Mm}^{3}$ of air fall tephra (Hall et al., 2015; Romero et al., 2017). These Vulcanian events are preceded by abrupt onsets or little precursory activity (e.g., Kim et al., 2014; Hall et al., 2015;
Parra et al., 2015; Romero et al., 2017).This is in agreement with volcano degassing, which was more or less continuous between 1999 and late 2008, but then changed to episodic activity without significant degassing during quiescence periods (Arellano et al., 2008; Hidalgo et al., 2015).

\section{Sampling and analytical methods}

\subsection{Tephra samples}

For this study we analyzed 47 samples collected between 1999 and 2013 (Fig. 1; Table 1). The ash samples from 1999 to 2005 were systematically collected by members of the Instituto Geofísico of Escuela Politécnica Nacional (IG-EPN) at distances of $5-20 \mathrm{~km}$ from the crater. The samples have been preserved in cool and dry conditions. During the catastrophic 2006 explosive activity, tephra sampling was carried out as soon as possible after the eruptive activity $(<24 \mathrm{~h})$. Since 2007 and up to 2012, the IG-EPN members used a series of "ashmeters" which consist of plastic recipients $20 \mathrm{~cm}$ diameter and $20 \mathrm{~cm}$ height, installed at a distance $<20 \mathrm{~km}$ from the crater (Bustillos, 2010; Bustillos and Mothes, 2010). These ash-meters were installed below the most frequent dispersal pattern of the ash, to the west of the volcano (Fig. 1). This instrumental monitoring, the reports of volcanic activity, and sample collection have been also enhanced by the help of volunteer community members since 2000 , locally known as vigías (watchmen) (e.g., Stone et al., 2014; Mothes et al., 2015).

\subsection{Tephra lithologies and textures}

The lithological and textural descriptions of tephra components are based on the standard classification of Heiken and Wholetz (1985). We used two main procedures for the lithology and texture characterization of ash samples: 1) Representative tephra samples (homogenized, quartered and $<2 \mathrm{~mm}$ diameter; coarse to very fine ash) were analyzed using a binocular microscope. The relative proportions (\%) of each particle type were determined through hand picking using fine forceps. They were distributed over glass plates, allowing the identification of their components. 2) By using the scanning electron microscope (SEM), a technique used since the last decades for description of ash particles 
TABLE 1. PHYSICAL FEATURES OF THE SAMPLES ANALYZED WITHIN THIS CONTRIBUTION.

\begin{tabular}{|c|c|c|c|c|c|c|}
\hline Sample & D (km) & Date & $\begin{array}{l}\text { Mass } \\
(\mathrm{g})\end{array}$ & $\begin{array}{l}\text { Bulk density } \\
\text { (g/cm3) }\end{array}$ & $\begin{array}{l}\text { True density } \\
(\mathrm{g} / \mathrm{cm} 3)\end{array}$ & $\begin{array}{c}\text { Porosity } \\
\text { (\%) }\end{array}$ \\
\hline 1 & 7.4 & 06.10 .1999 & 28.86 & 1.625 & 2.699 & 39.8 \\
\hline 2 & 7.4 & 21.07 .2000 & 94.6 & 1.782 & 2.79 & 36.1 \\
\hline 3 & 7.4 & 10.08 .2001 & 16.28 & 1.705 & 2.748 & 38 \\
\hline 4 & 8.5 & 16.09 .2001 & 47.36 & 1.421 & 2.727 & 47.9 \\
\hline 5 & 8.5 & 17.03 .2002 & 30.61 & 1.334 & 2.612 & 48.9 \\
\hline 6 & 8.3 & 02.10 .2002 & 60.58 & 1.42 & 2.771 & 48.8 \\
\hline 7 & 8.3 & 07.10 .2003 & 11.08 & 1.336 & 2.618 & 49 \\
\hline 8 & 8.4 & 08.11 .2003 & 106.61 & 1.569 & 2.689 & 41.7 \\
\hline $8 \mathrm{~A}$ & 8.4 & 17.07.2004 & - & - & - & - \\
\hline 9 & 6.5 & 20.04 .2006 & 69.71 & 1.45 & 2.779 & 47.8 \\
\hline $9 \mathrm{~A}$ & 21 & 26.05 .2006 & 301.86 & 1.54 & 2.705 & 43.1 \\
\hline $9 \mathrm{~B}$ & 21 & 24.08 .2006 & 458.56 & 1.233 & 2.753 & 55.2 \\
\hline 10 & 6.6 & 27.07 .2007 & 321.523 & 1.58 & 2.765 & 42.9 \\
\hline 11 & 6.6 & 05.08 .2007 & 78.32 & 1.588 & 2.878 & 44.8 \\
\hline 12 & 13 & 09.12 .2007 & 117.64 & 1.393 & 2.648 & 47.4 \\
\hline 13 & 6.6 & 05.02 .2008 & 32.36 & 0.614 & 2.341 & 73.8 \\
\hline 14 & 6.5 & 06.02 .2008 & 79.9 & 0.666 & 2.588 & 74.3 \\
\hline 15 & 6.6 & 07.02 .2008 & 78.82 & 1.375 & 2.709 & 49.2 \\
\hline 16 & 13 & 10.02 .2008 & 102.57 & 1.493 & 2.695 & 44.6 \\
\hline 17 & 9.5 & 21.06.2009 & 12.11 & 1.445 & 2.733 & 47.1 \\
\hline I & 9.5 & 01.01 .2010 & - & 1.017 & 2.527 & 59.8 \\
\hline II & 9.5 & 10.02 .2010 & - & 1.353 & 2.72 & 50.3 \\
\hline 18 & 6.6 & 17.02 .2010 & 191.31 & 1.38 & 2.775 & 50.3 \\
\hline $18 \mathrm{I}$ & 3.2 & 28.05 .2010 & 30.06 & - & - & - \\
\hline III & 21 & 28.05 .2010 & - & 0.665 & 2.028 & 67.2 \\
\hline IV & 21 & 22.11 .2010 & - & 1.51 & 2.868 & 47.4 \\
\hline $18 \mathrm{~A}$ & 8.3 & 23.12 .2011 & 39.45 & 1.433 & 2.775 & 48.4 \\
\hline $18 \mathrm{~B}$ & 6.6 & 27.12 .2011 & 71.76 & 1.543 & 2.694 & 42.7 \\
\hline $19 \mathrm{~A}$ & 3 & 04.02 .2012 & 58.07 & 1.191 & 2.52 & 52.7 \\
\hline 19 & 21 & 10.02 .2012 & 383.63 & 1.358 & 2.626 & 48.3 \\
\hline 19B & 6.5 & 23.02 .2012 & 131.65 & - & - & - \\
\hline $19 \mathrm{C}$ & 6.5 & 17.06 .2012 & 293.67 & - & - & - \\
\hline $19 \mathrm{D}$ & 6.5 & 23.06 .2012 & 103.53 & - & - & - \\
\hline $19 \mathrm{E}$ & 6.6 & 10.08 .2012 & 29.98 & - & - & - \\
\hline $19 \mathrm{~F}$ & 6.6 & 13.08 .2012 & 36.63 & - & - & - \\
\hline 20 & 21 & 23.08 .2012 & 248.37 & 1.223 & 2.709 & 54.9 \\
\hline $20 \mathrm{~A}$ & 6.6 & 23.08 .2012 & 40.07 & - & - & - \\
\hline 21 & 8.3 & 24.08 .2012 & 82.96 & 1.447 & 2.692 & 46.2 \\
\hline $21 \mathrm{~A}$ & 6.6 & 31.08 .2012 & 42.37 & - & - & - \\
\hline 22 & - & 16.12 .2012 & 59.37 & - & - & - \\
\hline 23 & 8.4 & 17.12 .2012 & 306.97 & - & - & - \\
\hline 24 & 6.5 & 20.12 .2012 & 5.85 & - & - & - \\
\hline 25 & 6.5 & 21.12 .2012 & 28.05 & - & - & - \\
\hline 26 & 6.5 & 23.12 .2012 & 16.83 & - & - & - \\
\hline 27 & 6.5 & 17.03 .2013 & 107.16 & - & - & - \\
\hline 28 & 6.5 & 24.04 .2013 & 321.74 & - & - & - \\
\hline 29 & 6.5 & 10.05 .2013 & 278.61 & - & - & - \\
\hline
\end{tabular}

$\mathrm{D}$ is the distance from the crater measured in $\mathrm{km}$. Towns can be tracked at figure 1. 
(e.g., Heiken and Wohletz, 1985; Sherdian and Marshall, 1983; Wholetz, 1986; Dellino and Kyriakopoulos, 2003). The SEM analyses were carried out using a Tescan-Vega (Bruker) instrument operating at $15.0 \mathrm{kV}$. The ash grains, previously selected under the binocular microscope, were placed inside a circular slide ( $1 \mathrm{~cm}$ diameter) on double-sided coal tape, as suggested by Lautze et al., 2012. The samples were coated with a thin metallic layer (200A gold in 20 seconds) prior to analysis in the SEM.

\subsection{Grain size}

Tephra was mechanically sieved from 63 to $2,000 \mu \mathrm{m}(-1$ to $4 \Phi)$ at regular steps of $0.5 \Phi$ $\left(\Phi=-\log _{2} \mathrm{D} / \mathrm{D}_{0}\right.$, with $\mathrm{D}$ being the particle diameter and $\mathrm{D}_{0}$ a reference diameter as $1 \mathrm{~mm}$ ), using a Fritsch analysette instrument, during a period of 3-5 minutes in order to avoid the over-fracturing of tephra. Respective grain size fractions were weighted and their mass fraction ( $\mathrm{wt} \%$ ) was determined using the total mass of each sample. The sample statistics $\left(\mathrm{M}_{\mathrm{d}}=\right.$ median; $\mathrm{M}_{\mathrm{z}}=$ mean; $\sigma_{1}=$ sorting or standard deviation; $\mathrm{S}_{\mathrm{k}}=$ skewness; $\mathrm{K}_{\mathrm{G}}=$ kurtosis) were then calculated using the Gradisat package (Blott and Pye, 2001) which uses the Method of Moments in Microsoft Visual Basic programming language. Linear interpolation is used to calculate statistical parameters by the Folk and Ward (1957) graphical method, and to derive physical descriptions (such as "very coarse sand" and "moderately sorted") (Blott and Pye, 2001). We also compared these descriptions with the classification of Cas and Wright (1987) which is commonly used for the study of volcanic deposits. After measuring the $<63 \mu \mathrm{m}(4 \Phi)$ ash fraction, we used the method of Horwell (2007) to estimate both "thoracic" $(<10 \mu \mathrm{m} ; 6.7 \Phi)$ and "respirable" $(<4 \mu \mathrm{m}$; $8 \Phi)$ ash amounts particles.

\subsection{Chemistry and mineralogy}

The major element chemical characterization of bulk ash (particles finer than 4Ф) samples was analyzed by Energy Dispersion Spectrometer (EDS) for SEM with a Qantax EDS (Bruker instrument). The procedure consisted in the mapping and averaging of 100 points in order to avoid heterogeneity effects from individual particles. These particles were not separated prior geochemical analyses, thus the results from samples exclusively compound by fresh juvenile particles are discussed. Work distance was $26 \mathrm{~mm}$, with Secondary Electron Detector (SE) and the software Spirit 1.8 with a detection limit of $1 \%$ for the recognized elements.

Mineralogy was characterized from pulverized samples of ash (particles finer than 5Ф) at the X-Ray diffractometer (XRD) D8-Advance. The qualitative and quantitative identification of mineral phases were carried out with the software Diffrac ${ }^{\text {plus }}$ (EVA) and these phases were compared with the XRD spectrums of the International Center of Diffraction Data (ICDD) database. In the case of minerals with continue compositions (e.g., plagioclases, from albite to anorthite) these are named as the amount of one of these two end-members changes (e.g., anorthite), producing different $\mathrm{X}$-Ray powdered diffraction patterns and intensities (e.g., Goodyear and Duffin, 1954). Additionally, a semi-quantitative analysis of amorphous material was done with Topas 4.2 software.

\section{Results}

\subsection{Lithological and textural characteristics of tephra}

Based in lithology, we have distinguished five types of particles within the tephra samples.

\subsubsection{Scoria}

It can be dark (black), brown or reddish. Black scoria (Fig. 3A) correspond to dark, sometimes glassy particles, generally with vesicles. Brown scoria is a transparent or semi-transparent (glassy) brown material with vesicles (Fig. 3A). Reddish scorias are subrounded to sub-angular vesiculated particles altered by hidrothermal processes (Fig. 3B).

\subsubsection{Pumice}

Particle of a clear to intermediate gray-color, highly vesicular glassy material whose vesicles are sub-spherical (Fig. 3C).

\subsubsection{Lithics}

lithics correspond to dense angular rocks fragments, black or reddish in color, blocky, porphyritic or microcrystalline and non-vesicular (Fig. 3D). Even if part of these particles might be juvenile, they are considered as lithics because they were crystallized pior to their fragmentation (in older lavas or hipabisal intrusions). 

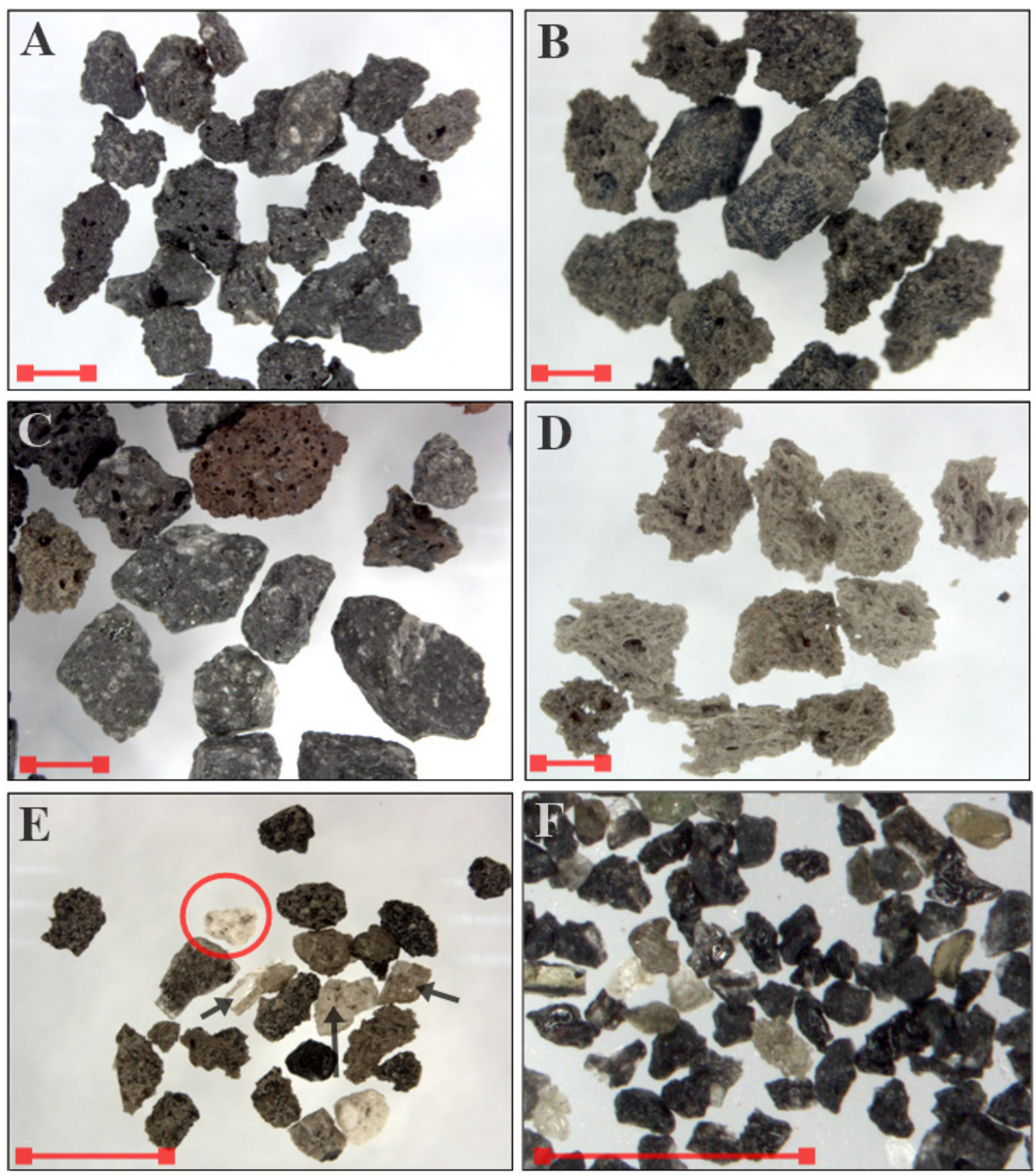

FIG. 3. Lithologic components identified by optical microscope in ash samples from Tungurahua. A. Black scoria fragment in sample 5; B. Brown scoria in sample 9B; C. Reddish scoria and lithics found in sample 19A; D. Pumice particles with elongated vesicles from sample 13; E. Free crystals (mainly plagioclase, black arrows) found in sample 17. Also, an aggregate is highlighted with a red circle; F. Glass shards in sample 8. For scale purposes, red bars are $1 \mathrm{~mm}$ in length.

\subsubsection{Crystals}

Free crystals are sub-rounded and idiomorphic fragments (Fig. 3E).

\subsubsection{Glass shards}

Glass shards are transparent to semi-transparent, uncolored or clear brown, dense and non-vesicular material (Fig. 3F). Sharp perimeters and conchoidal fractures are typically observed. White spherical aggregates of finer fragments are ocassionally found (Fig. 3E).
Thus, we considerate as fresh juvenile constituents of tephra only scoria, pumice, free crystals and glass shards as they directly result from the primarly magma fragmentation. In contrast, lithics and altered fragments such as reddish scoria are interpreted to be accidental.

Quantitative variations of these components are reported in figure 4. Also, we qualitatively describe the juvenile (mostly glassy) particles in function of their morphology (vesicularity, shape and surface; Fig. 5) as follows: 


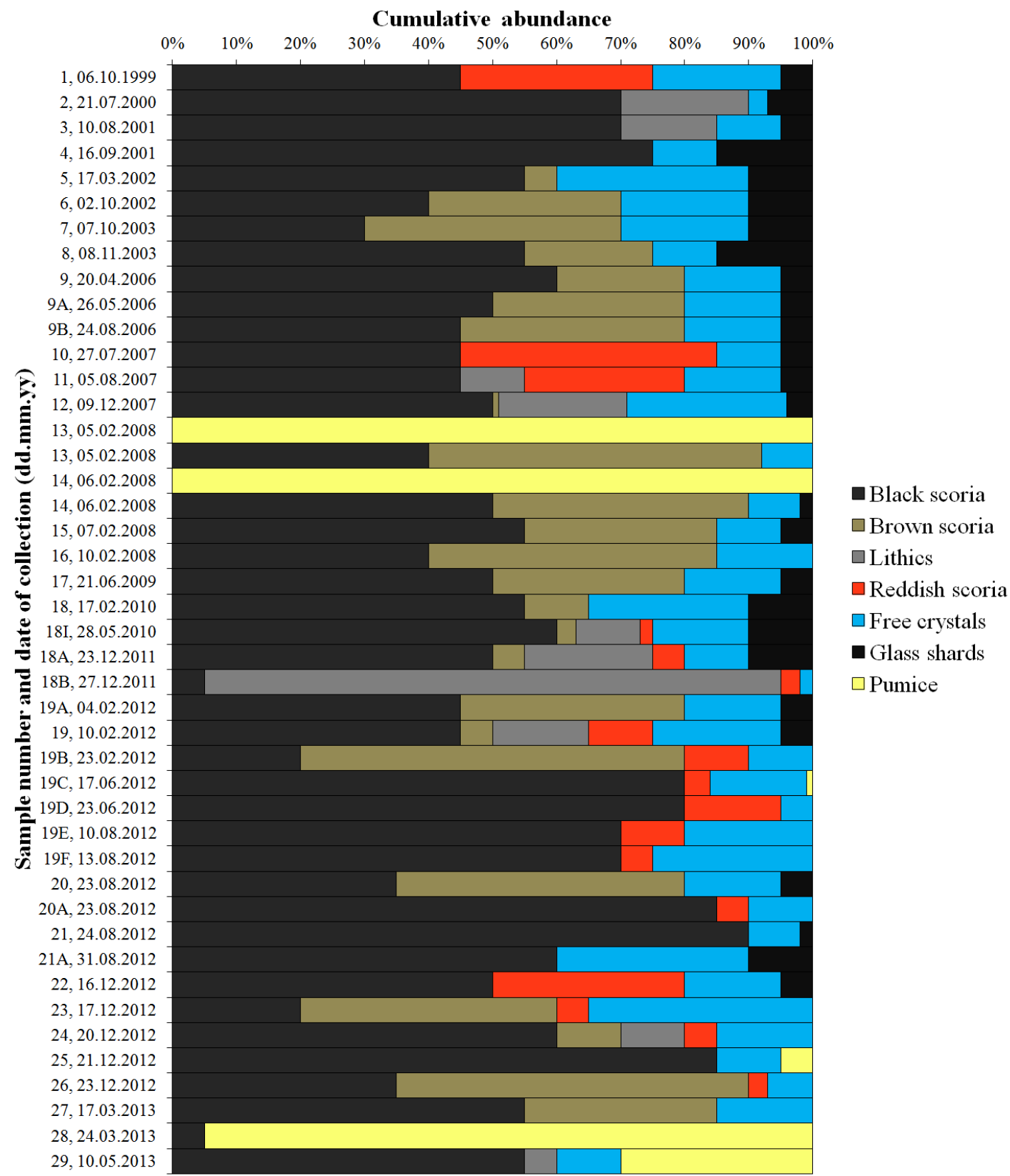

FIG. 4. Relative proportion of the different components of tephra samples of eruptions between 1999 and 2012 at Tungurahua volcano.

\subsubsection{Apparent vesicularity}

The amount (\%) of vesicles is optically estimated within the selected particles. We classify particles as none vesicular (0\%; Fig. 5A1), lowly vesicular (1-25\%; Fig. 5B1), moderately vesicular (26-50\%; Fig. 5C1) and highly vesicular (>50\%; Fig. 5D1).

\subsubsection{Shape}

The particles are grouped into four categories: 1) IVW or inter-vesicular walls (Fig. 5A2), 2) fluid (spheric or tear-shaped glassy droplets; Fig. 5B2), 3) filamentous (very elongated particles, such as Peleé tears or fibers; Fig. 5C2) and 4) blocky particles (generally compact and porous grains; Fig. 5D2). 

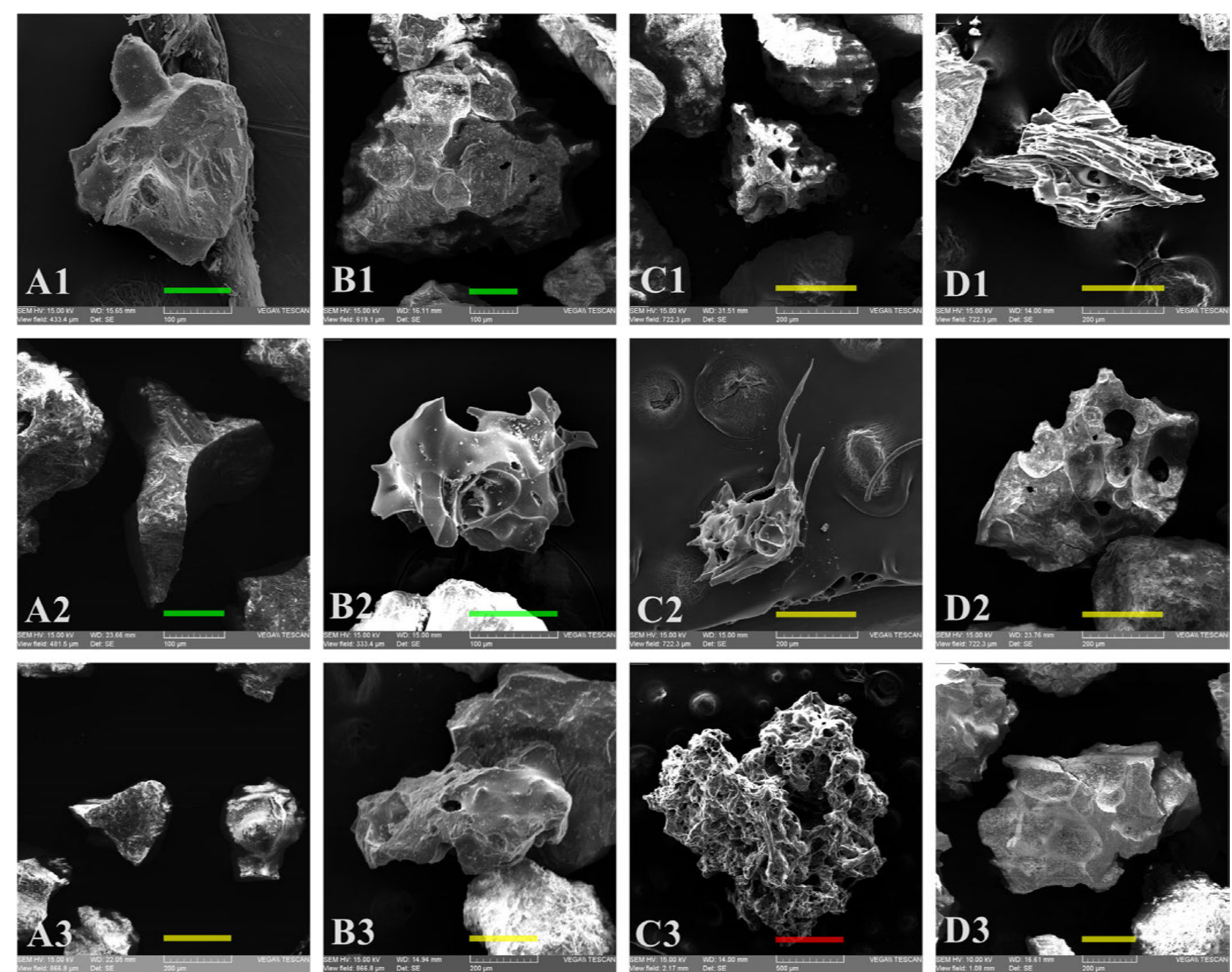

FIG. 5. Qualitative characterization of juvenile ash particles using SEM-EDS in function of their vesicularity (from A1 to D1), shape (from A2 to D2) and surface/perimeter (from A3 to D3). A1: Sample 19; B1: Sample 6; C1: Sample 1; D1: Sample 13; A2: Sample 5; B2: Sample 19A; C2: Sample 13; D2: Sample 4; A3: Sample 5; B3: Sample 9; C3: Sample 13; D3: Sample 20. For sample details please refer to table 1 and figure 1. Scale bars correspond to $100 \mu \mathrm{m}$ (green), $200 \mu \mathrm{m}$ (yellow) and $500 \mu \mathrm{m}$ (red). 


\subsubsection{Surface or perimeter}

This category includes: 1) smoothed particles (Fig. 5A3), 2) molten surfaces (mild, bulbous and waken particle faces; Fig. 5B3), 3) jagged perimeters (as product of abundant blowed up vesicles; Fig. 5C3) and 4) broken grains as product of recycling of older pyroclasts (Fig. 5D3).

\subsection{Lithological and textural variations of tephra through time}

\subsubsection{Phase I}

The first tephra sample collected in October 1999 was dominantly compound of black scoria $(45 \%)$, with a large proportion of altered reddish scoria $(30 \%)$, free crystals (20\%) and scarce glass shards (5\%) (Fig. 4). Glassy particles were moderately vesicular, with jagged perimeter. Subsequent ash emissions up to 2001 ejected increasing black scoria (70-75\%), lithics $(0-20 \%)$, free crystals $(5-10 \%)$ and increasing glass shards (5-15\%) (Fig.4) suggesting more participation of juvenile magma. These glassy particles had low vesicularity and blocky shapes (Table 2). Between 2002 and 2003 the ash was compound of dominant black scoria $(30-55 \%)$, brown scoria $(5-40 \%)$, decreasing amounts of free crystals $(10-30 \%)$ and relative stable amounts of glass shards (10-15\%) (Fig. 4). These glassy particles had none-to-low in vesicularity, shaped as inter-vesicular walls and their perimeter was smoothed or molten (Table 2).

\subsubsection{Phase II}

In Phase II, black scoria, brown scoria, free crystals and glass shards were observed. Since April 2006 and up to August 2006, the amount of black scoria decreased from 60 to $45 \%$, while the participation of brown scoria increased from 20 to $35 \%$ (Fig. 4). The free crystals remained constant in time (15\%) as similarly to glass shards (5\%) (Fig. 4). Glassy particles collected in 2006 (before the August 2006 eruption) had none, low or moderate vesicularity (vesicles were, in most of cases subspherical), with blocky shape and broken or jagged perimeters (very scarce molten perimeters) (Table 2). After the paroxysmal eruption of 16 August 2006, the morphology of ash grains evolved in 24 August to moderately or highly vesicular (vesicles were subrounded or slightly elongated), with blocky shapes and the perimeters of these particles were smoothed, molten and jagged (Table 2).

\subsubsection{Phase III}

Within the 2007 ash samples there was a new incursion of altered scoria and lithics (30-45\% and $10-20 \%$ respectively), even when these samples are also dominated by $45-50 \%$ black scoria, $10-25 \%$ free crystals and about $5 \%$ glass shards, with very small amounts of brown scoria (1-2\%) (Fig. 4). The glassy particles were not vesicular or moderately vesicular, with blocky shape and smoothed and molten perimeters (Table 2). Two samples collected by 5-6 February 2008 were exclusively compound of pumice, which had low to high vesicularity, fluid and filamentous shapes and molten or jagged perimeters (Fig. 4). Their vesicles were subrounded to elongated, forming "tubes". Hereafter the tephra emissions ejected increasing amounts of black scoria (50-60\%), increasing free crystals $(7-20 \%)$, increasing glass shards ( $<5$ to $10 \%$ ) and decreasing brown scoria ( $<5$ to $40 \%$ ) up to Feruary 2010 (Fig. 4). Glassy particles were low to moderately vesicular, blocky shaped and with smoothed, molten and jagged perimeters (Table 2).

\subsubsection{Phase IV}

The components of the ashes since 2010 up to 2013 show chaotic patterns in time if compared to the pre-2010 eruptions. In fact, glass shards $(<5$ to $10 \%$ ), altered scoria ( $<5$ to $30 \%)$, brown scoria (10$45 \%)$ and lithics (10-90\%) are sporadically present (Fig. 4). Black scoria remains always present but in varying proportion (50-90\%), similarly to free crystals $(<10$ to $30 \%$ ) (Fig. 4 ). The glassy particles were not vesicular or exhibited moderate-to-high vesicularity, a widespread variety of shapes (fluid, filamentous and blocky) with smoothed and broken perimeters (Table 2). A noticeable change occurs since December 2012 when glass shards are not longer observed (Fig. 4). However, the morphology of glassy particles (scoria and pumice) revealed to be low-to-moderate in vesicularity with molten and broken perimeters (Table 2). Also, relevant amounts (25-95\%) of pumice are observed within the samples collected in March and May 2013 (Fig. 4).

\subsection{Grain size}

We observed unimodal (Fig. 6A; 11.9\%), bimodal (Fig. 6B; 76.2\%) and trimodal (Fig. 6C; 11.9\%) grain size distributions (GSD) within the tephra samples (Table 3). Between 1999 and 2009, deposits 
TABLE 2. SYNTHESIS OF TEXTURE AND STRUCTURE OBSERVED ON JUVENILE PARTICLES ERUPTED BY TUNGURAHUA BETWEEN 1999 AND 2013 USING SEM-EDS.

\begin{tabular}{|c|c|c|c|c|c|c|c|c|c|c|c|c|c|}
\hline \multirow{3}{*}{ Sample } & \multirow{3}{*}{ Date } & \multicolumn{12}{|c|}{ Glassy particles } \\
\hline & & \multicolumn{4}{|c|}{ Vesicularity } & \multicolumn{4}{|c|}{ Shape } & \multicolumn{4}{|c|}{ Surface /perimeter } \\
\hline & & none & low & moderate & high & IVW* & fluid & filamentous & blocky & smoothed & molten & jagged & broken \\
\hline 1 & 06.10 .1999 & & & & & & & & & & & & \\
\hline 2 & 21.07 .2000 & & & & & & & & & & & & \\
\hline 3 & 10.08 .2001 & & & & & & & & & & & & \\
\hline 4 & 16.09 .2001 & & & & & & & & & & & & \\
\hline 5 & 17.03 .2002 & & & & & & & & & & & & \\
\hline 6 & 02.10 .2002 & & & & & & & & & & & & \\
\hline 9 & 20.04 .2006 & & & & & & & & & & & & \\
\hline $9 \mathrm{~A}$ & 26.05 .2006 & & & & & & & & & & & & \\
\hline 9B & 24.08 .2006 & & & & & & & & & & & & \\
\hline 10 & 27.07 .2007 & & & & & & & & & & & & \\
\hline 11 & 05.08 .2007 & & & & & & & & & & & & \\
\hline 12 & 09.12 .2007 & & & & & & & & & & & & \\
\hline 13 & 05.02 .2008 & & & & & & & & & & & & \\
\hline 14 & 06.02 .2008 & & & & & & & & & & & & \\
\hline 15 & 07.02 .2008 & & & & & & & & & & & & \\
\hline 18 & 17.02 .2010 & & & & & & & & & & & & \\
\hline $18 \mathrm{I}$ & 28.05 .2010 & & & & & & & & & & & & \\
\hline $19 \mathrm{~A}$ & 04.02 .2012 & & & & & & & & & & & & \\
\hline 19 & 10.02 .2012 & & & & & & & & & & & & \\
\hline 20 & 23.08 .2012 & & & & & & & & & & & & \\
\hline 21 & 24.08 .2012 & & & & & & & & & & & & \\
\hline
\end{tabular}

Shading positions indicate the occurrence of the respective textural feature. IVW* correspond to inter-vesicular walls. 

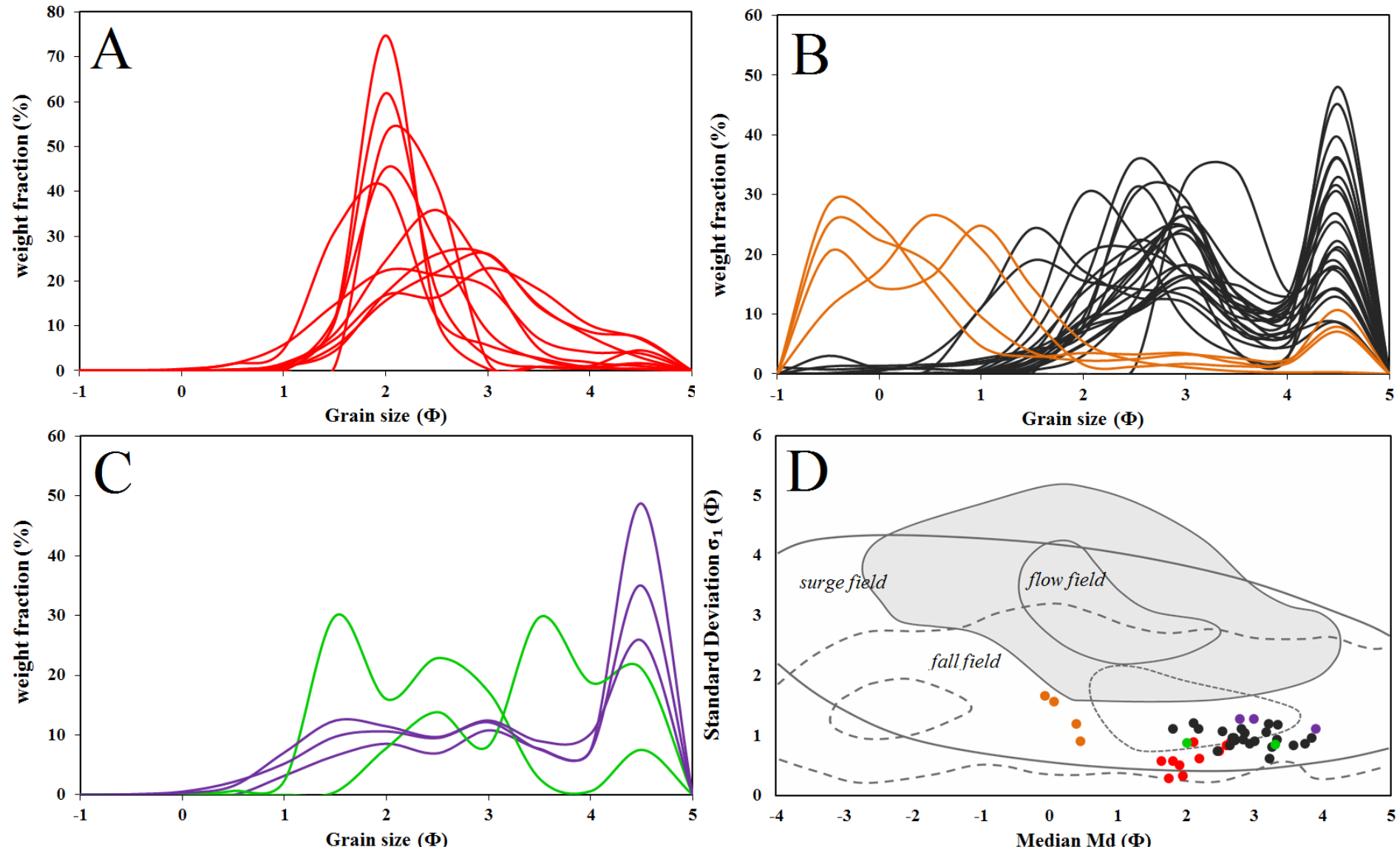

$\begin{array}{ll}\bullet \text { Unimodal: } & \bullet \text { Bimodal: } \\ \text { 2,6,8,9A,10,11,15,16,21,22 } & 1,3,4,7,9,9 \mathrm{~B}, 12,17,18,18 \mathrm{~A}, 18 \mathrm{~B}, 19 \mathrm{~B} \\ & , 19 \mathrm{C}, 19 \mathrm{D}, 19 \mathrm{E}, 19 \mathrm{~F}, 20,20 \mathrm{~A}, 21 \mathrm{~A}, 24,\end{array}$

- Bimodal: 13,14,18I,19A

- Trimodal: $18 \mathrm{~B}, 25,29$

- Trimodal: 5 and 23

FIG. 6. Grain size distribution (GSD) of tephra fall samples. A. Unimodal GSD (red); B. Bimodal GSDs, where two main bimodal populations are recognized (orange and dark grey); C. Trimodal GSD with also two main populations (green and violet); D. Walker (1971) classification for GSD of pyroclastic deposits. The samples here studied plot in the field of fall deposits. Colours from lines and circles correspond to each cluster of unimodal or polymodal samples. 
TABLE 3. GRAIN SIZE PARAMETERS OF FOLK AND WARD (1957) FOR 42 SAMPLES SIEVED MECHANICALLY.

\begin{tabular}{|c|c|c|c|c|c|c|c|c|c|c|c|c|}
\hline \multirow{2}{*}{ Sample } & \multicolumn{6}{|c|}{ Folk and Ward (1957) statistics (Ф) } & \multicolumn{3}{|c|}{ Modes } & \multicolumn{3}{|c|}{ Fine to extremely fine ash } \\
\hline & Md & $\mathbf{M z}$ & $\sigma 1$ & Sk & KG & $\mathbf{S}$ & M1 & M2 & M3 & $<63 \mu \mathrm{m}$ & $<10 \mu \mathrm{ma}$ & $<4 \mu \mathrm{mb}$ \\
\hline 1 & 2.87 & 3.02 & 1.04 & 0.06 & 0.76 & $\mathrm{P}$ & 4.23 & 2.24 & - & 25.29 & 6.55 & 2.11 \\
\hline 2 & 2.11 & 2.12 & 0.89 & 0.07 & 1.08 & M & 2.24 & - & - & 3.85 & 0.92 & 0.19 \\
\hline 3 & 2.94 & 3.05 & 0.86 & 0.11 & 0.87 & M & 2.74 & 4.23 & - & 17.08 & 4.29 & 1.2 \\
\hline 4 & 1.82 & 2.03 & 1.1 & 0.3 & 0.98 & $\mathrm{P}$ & 1.25 & 4.23 & - & 8.66 & 2.11 & 0.49 \\
\hline 5 & 3.31 & 3.23 & 0.85 & -0.16 & 0.86 & M & 3.24 & 4.23 & 2.24 & 21.1 & 5.38 & 1.62 \\
\hline 6 & 1.96 & 1.98 & 0.32 & 0.08 & 0.74 & VW & 1.75 & - & - & 1.58 & 0.38 & 0.07 \\
\hline 7 & 3.23 & 3.34 & 0.61 & 0.23 & 0.83 & MW & 3.24 & 4.23 & - & 18.68 & 4.72 & 1.36 \\
\hline 8 & 2.2 & 2.21 & 0.61 & 0.02 & 1.09 & MW & 2.24 & - & - & 1.03 & 0.24 & 0.05 \\
\hline 9 & 2.46 & 2.64 & 0.74 & 0.37 & 1.26 & M & 2.24 & 4.23 & - & 8.58 & 2.09 & 0.49 \\
\hline $9 \mathrm{~A}$ & 2.6 & 2.63 & 0.83 & 0.09 & 1.02 & M & 2.74 & - & - & 7.3 & 1.77 & 0.4 \\
\hline $9 \mathrm{~B}$ & 2.81 & 2.89 & 1.11 & -0.03 & 1.04 & $\mathrm{P}$ & 2.74 & 4.23 & - & 17.81 & 4.49 & 1.27 \\
\hline 10 & 1.81 & 1.88 & 0.58 & 0.4 & 2.33 & MW & 1.75 & - & - & 4.54 & 1.09 & 0.23 \\
\hline 11 & 1.65 & 1.67 & 0.58 & 0.14 & 1.27 & MW & 1.75 & - & - & 0.31 & 0.07 & 0.01 \\
\hline 12 & 3.58 & 3.44 & 0.84 & -0.29 & 0.73 & M & 4.23 & 3.24 & - & 39.61 & 10.76 & 4.21 \\
\hline 13 & 0.4 & 0.49 & 1.18 & 0.34 & 1.87 & $\mathrm{P}$ & 0.25 & 4.23 & - & 7.08 & 1.72 & 0.38 \\
\hline 14 & 0.07 & 0.63 & 1.56 & 0.58 & 1.42 & $\mathrm{P}$ & -0.74 & 4.23 & - & 7.88 & 1.92 & 0.44 \\
\hline 15 & 2.5 & 2.53 & 0.74 & 0.09 & 1.03 & M & 2.24 & - & - & 2.91 & 0.69 & 0.14 \\
\hline 16 & 2.66 & 2.64 & 0.89 & -0.01 & 0.92 & M & 2.74 & - & - & 7.03 & 1.7 & 0.38 \\
\hline 17 & 3.17 & 3.13 & 1.05 & -0.15 & 0.79 & $\mathrm{P}$ & 4.23 & 2.74 & - & 30.47 & 8.03 & 2.8 \\
\hline 18 & 2.69 & 2.88 & 0.95 & 0.22 & 0.89 & M & 2.74 & 4.23 & - & 17.72 & 4.46 & 1.26 \\
\hline $18 \mathrm{I}$ & -0.07 & 0.67 & 1.66 & 0.65 & 1.05 & $\mathrm{P}$ & -0.74 & 4.23 & - & 10.71 & 2.63 & 0.64 \\
\hline $18 \mathrm{~A}$ & 2.11 & 2.31 & 1.2 & 0.22 & 0.85 & $\mathrm{P}$ & 1.25 & 4.23 & - & 12.85 & 3.18 & 0.82 \\
\hline $18 \mathrm{~B}$ & 2.79 & 2.75 & 1.28 & -0.09 & 0.64 & $\mathrm{P}$ & 4.23 & 1.25 & 2.74 & 25.84 & 6.7 & 2.18 \\
\hline $19 \mathrm{~A}$ & 0.46 & 0.38 & 0.89 & -0.04 & 0.88 & M & 0.75 & -0.74 & - & 0.29 & 0.07 & 0.01 \\
\hline 19 & 3.35 & 3.12 & 1.17 & -0.34 & 0.77 & $\mathrm{P}$ & 4.23 & 2.74 & - & 37.18 & 10.02 & 0.59 \\
\hline $19 \mathrm{~B}$ & 3.26 & 3.33 & 0.8 & 0.05 & 0.65 & M & 4.23 & 2.74 & - & 36.01 & 9.67 & 0.57 \\
\hline $19 \mathrm{C}$ & 3.01 & 3.13 & 0.9 & 0.11 & 0.68 & M & 4.23 & 2.74 & - & 26.7 & 6.94 & 0.38 \\
\hline $19 \mathrm{D}$ & 2.65 & 2.87 & 0.83 & 0.33 & 1 & M & 2.24 & 4.23 & - & 14.22 & 3.54 & 0.17 \\
\hline $19 \mathrm{E}$ & 3.75 & 3.49 & 0.85 & -0.44 & 0.7 & M & 4.23 & 2.74 & - & 45.13 & 12.48 & 0.79 \\
\hline $19 \mathrm{~F}$ & 3.34 & 3.27 & 0.92 & -0.16 & 0.69 & M & 4.23 & 2.74 & - & 36.2 & 9.72 & 0.57 \\
\hline 20 & 3.85 & 3.46 & 0.95 & -0.57 & 0.72 & M & 4.23 & 2.74 & - & 48.03 & 13.41 & 0.86 \\
\hline $20 \mathrm{~A}$ & 2.72 & 2.83 & 0.92 & 0.15 & 0.91 & M & 2.74 & 4.23 & - & 13.93 & 3.46 & 0.17 \\
\hline 21 & 1.91 & 1.96 & 0.5 & 0.18 & 1.15 & MW & 1.75 & - & - & 1.66 & 0.4 & 0.08 \\
\hline $21 \mathrm{~A}$ & 2.85 & 3 & 0.93 & 0.16 & 0.8 & M & 2.74 & 4.23 & - & 20.7 & 5.27 & 1.58 \\
\hline 22 & 1.76 & 1.76 & 0.29 & 0.03 & 1.39 & VW & 1.75 & - & - & 0.44 & 0.1 & 0.02 \\
\hline 23 & 2.02 & 2.03 & 0.88 & 0.19 & 1.06 & M & 1.25 & 2.24 & 4.23 & 7.53 & 1.83 & 0.41 \\
\hline 24 & 2.54 & 2.8 & 1.06 & 0.26 & 0.71 & $\mathrm{P}$ & 4.23 & 2.24 & - & 22.22 & 5.69 & 1.75 \\
\hline 25 & 3.9 & 3.36 & 1.11 & -0.67 & 0.76 & $\mathrm{P}$ & 4.23 & 2.74 & 1.75 & 48.73 & 13.64 & 5.9 \\
\hline 26 & 2.71 & 3.01 & 0.95 & 0.33 & 0.6 & M & 4.23 & 2.24 & - & 32.98 & 8.76 & 3.16 \\
\hline 27 & 2.19 & 2.63 & 1.11 & 0.45 & 0.8 & $\mathrm{P}$ & 1.75 & 4.23 & - & 21.2 & 5.41 & 1.63 \\
\hline 28 & 3.21 & 3.11 & 1.19 & -0.27 & 0.93 & $\mathrm{P}$ & 4.23 & 2.74 & - & 31.46 & 8.32 & 2.94 \\
\hline 29 & 3 & 2.89 & 1.27 & -0.18 & 0.66 & $\mathrm{P}$ & 4.23 & 2.74 & 1.75 & 35.01 & 9.36 & 3.47 \\
\hline
\end{tabular}

Md: median; Mz: mean; $\boldsymbol{\sigma 1}$ : sorting; Sk: skewness; KG: Kurtosis. For sample distribution modes 1, 2 and 3 are M1, M2 and M3. Also, for sample sorting (S) the label meaning is defined as follows: P: poorly sorted, M: moderately sorted; W: Well sorted and VW: Very well sorted. a. Calculated using the method (1) of Horwell (2007): $y=0.0009 x 2+0.236 x$, where $y$ is the cumulative $\%<10 \mu \mathrm{m}$ and $\mathrm{x}$ is the cumulative $\%<63 \mu \mathrm{m}$ fraction. b. Calculated using the method (2) of Horwell (2007): $\mathrm{y}=0.0016 \mathrm{x} 2+0.043 \mathrm{x}$, where $\mathrm{y}$ is the cumulative $\%<4 \mu \mathrm{m}$ and $\mathrm{x}$ is the cumulative $\%<63 \mu \mathrm{m}$ fraction. The correlation (R2) of methods (1) and (2) are 0.853 and 0.88 , respectively. The bold data correspond to the three highest values of finest ash fraction of all the samples. 
with unimodal and bimodal GSD's were frequently interspersed, but from 2009 to 2012 most of the samples had a bimodal or trimodal distribution. The tephra from the August 2006 eruptions is bimodal, with modes at 2.74 and $4.23 \Phi$ (medium to very fine ash). The trimodal GSD's are typical of samples from the 2002, 2011, 2012, and 2013 eruptions. According to the classification of Folk and Ward (1957), 37\% of the samples are poorly sorted, $50 \%$ are moderately sorted, $12.5 \%$ are moderately well sorted and 5\% are very well sorted (Table 3 ). The classification of Cas and Wright (1987) is currently the most used for volcanic deposits, and with their criteria $62.5 \%$ of the samples are very well sorted and $12.5 \%$ are well sorted. In general, average values of $\mathrm{M}_{\mathrm{d}}=2.48 \Phi$ (medium to fine ash), $\mathrm{M}_{\mathrm{z}}=2.54 \Phi$ (medium to fine ash), $\sigma_{1}=0.93$ (well sorted) $\Phi S_{k}=0.07 \Phi$ (asymmetrically positive) and $\mathrm{K}_{\mathrm{G}}=0.96 \Phi$ are observed for the whole dataset (Table 3). All samples are well classified as fall deposits according to the scheme of Walker (1973) (Fig. 6D).

The abundance of particles smaller than $4 \Phi$ varied from 0.3 to $48 \mathrm{wt} \%$ of the total ash samples, and frequently $(\sim 21 \%)$ it is $<5 \mathrm{wt} \%$ (Table 3 ). Nevertheless, in other cases $(\sim 12 \%)$ this fraction accumulates $35-40 \mathrm{wt} \%$. Samples with the highest content of $<4 \Phi$ ash (35-50 wt\%) were erupted in August $10^{\text {th }}$, August $23^{\text {rd }}$ and December $21^{\text {st }} 2012$, while other samples erupted in December 2007, February and August 2012 had also high amounts of fine ash (Table 3 ). In contrast, the lower amounts of ash finer than $4 \Phi$ were found during the eruptions of July and October 2002, July and August 2007, February 2009, February 2012 and August and December 2012 (samples 2, 6, 8, 10, 11, 15, 19A, 21, and 22). Sample 9B (August 24 ${ }^{\text {th }} 2006$ ) has an intermediate amount of fine ash (15-20\%) (Table 3).

The particles smaller than $6.7 \Phi$ ranged from 0.07 to $13.64 \mathrm{wt} \%$ in all samples, with an average of $4.9 \mathrm{wt} \%$, and the $<8 \Phi$ fraction ranged from 0.01 to $5.9 \mathrm{wt} \%$ with an average of $1.14 \mathrm{wt} \%$ (Table 3).

\subsection{Bulk ash geochemistry}

Due to the coexistence of different particle classes together in ash (including lithics and altered particles), only 21 of 43 geochemical analyses are considered as useful for describing the bulk geochemistry erupted materials, as they are exclusively compound by fresh juvenile particles (scoria, pumice, glass shards and free crystals) as shown in table 4. According to the total alkali-silica (TAS; Le Maitre, 1984) classification scheme (Fig. 7A), the samples from the whole eruptive style (Table 3 ) plot in the andesite compositional field, with a $\mathrm{SiO}_{2}$ range between 57.9 and $62.3 \mathrm{wt} \%$.

Harker diagrams are shown in figure $7 \mathrm{~B}-\mathrm{H}$. Linear trends are only identified in $\mathrm{FeO}, \mathrm{CaO}$, and $\mathrm{K}_{2} \mathrm{O}$ versus $\mathrm{SiO}_{2}$ variation diagrams, while a major scattering is observed in $\mathrm{TiO}_{2}, \mathrm{Al}_{2} \mathrm{O}_{3}$ and $\mathrm{MgO}$ contents. In general, samples collected in 2012-2013 are slighly enriched in $\mathrm{CaO}$ and $\mathrm{K}_{2} \mathrm{O}$ (Fig. $7 \mathrm{~F}$ and $7 \mathrm{H}$ ), but depleted in $\mathrm{MgO}$ and $\mathrm{Na}_{2} \mathrm{O}$ (Fig. $7 \mathrm{E}$ and $7 \mathrm{G}$ ) if they are compared with the samples that represent the 2001-2010 eruptions. $\mathrm{CaO}$ versus $\mathrm{MgO}$ (Fig. 7I), molar $\mathrm{K}_{2} \mathrm{O} / \mathrm{K}_{2} \mathrm{O}+\mathrm{CaO}$ versus $\mathrm{MgO}$ (Fig. 7J) and the pseudoternary system defined by Opx-An-Or (Fig. 7K) (Díaz-Alvarado et al., 2011; Castro, 2013) are particularly significant for visualizing linear trends in co-genetic igneous rocks. However, Tungurahua samples display a significant scattering for a scarce $\mathrm{SiO}_{2}$ variation. The higher $\mathrm{CaO}$ and $\mathrm{K}_{2} \mathrm{O}$ and lower $\mathrm{MgO}$ contents observed in the 2012-2013 samples regarding to the rest of the studied ash deposits separate two groups of samples in these diagrams.

\subsection{Mineralogy}

The ash mineralogy is characterized by the assemblage of plagioclase (plg; 58.4\%), pyroxene (px; 37.00\%) of both clinopyroxene (cpx; 29.98\%) and orthopyroxene (opx; 7.04\%) classes, olivine (ol; $3.38 \%$ ), and $1.40 \%$ of akermanite (ak) and magnetite (mag) (Table 5).

The recognized plagioclases corresponded to anorthite (16-31\%), andesine (13-22\%) and albite $(9-21 \%)$. The plg was generally observed in the ash samples (53-65\%), and its maximum relative proportion is found in the 2006 samples (62-65\%). Pyroxenes consist of both cpx and opx. The cpx was identified as diopside (9-20\%), pigeonite (7-18\%) and, in a few cases, of hedenbergite (1-3\%). On other hand, the only estantite was recognized for opx (3-12\%). In general, the highest proportions of px were found in ash samples from 2001 and 2002 eruptions (Table 5; 41-44\%). Olivine was forsteritic, varying from 2 to $9 \%$ and with its highest relative proportion in the samples of year 2003 (sample 7). As accessory minerals, akermanite and magnetite were found (Table 5). Akermanite varied from 1-2\%, 
TABLE 4. BULK ASH MAJOR ELEMENT CHEMICAL COMPOSITION FOR THE SAMPLES OF TUNGURAHUA VOLCANO COMPOUND EXCLUSIVELY BY JUVENILE PARTICLES, FROM ERUPTION OCCURRED BETWEEN 1999 AND 2013.

\begin{tabular}{|c|c|c|c|c|c|c|c|c|c|}
\hline \multirow{2}{*}{ Sample } & \multicolumn{8}{|c|}{ Oxide (wt\%) } & \multirow[b]{2}{*}{ Total } \\
\hline & $\mathrm{SiO}_{2}$ & $\mathrm{Al}_{2} \mathrm{O}_{3}$ & $\mathrm{FeO}$ & $\mathrm{CaO}$ & MgO & $\mathrm{Na}_{2} \mathrm{O}$ & $\mathrm{K}_{2} \mathrm{O}$ & $\mathrm{TiO}_{2}$ & \\
\hline 4 & 57.87 & 16.55 & 8.01 & 8.42 & 3.33 & 3.56 & 1.45 & 0.78 & 99.98 \\
\hline 5 & 60.16 & 17.19 & 6.69 & 7.04 & 2.27 & 3.55 & 2.14 & 0.98 & 100.02 \\
\hline 6 & 59.82 & 15.34 & 7.85 & 7 & 3.5 & 3.59 & 2.08 & 0.82 & 99.99 \\
\hline 7 & 59.64 & 15.68 & 8.12 & 7.18 & 3 & 3.84 & 1.61 & 0.92 & 100 \\
\hline 8 & 58.9 & 15.53 & 7.98 & 8.02 & 3.65 & 3.57 & 1.54 & 0.8 & 99.98 \\
\hline $9 \mathrm{~A}$ & 58.49 & 15.36 & 8.66 & 7.86 & 3.56 & 3.64 & 1.69 & 0.75 & 100.01 \\
\hline $9 B$ & 62.28 & 14.04 & 7.87 & 7.16 & 2.79 & 3.41 & 1.77 & 0.67 & 99.99 \\
\hline 13 & 57.98 & 15.44 & 9.22 & 7.6 & 3.48 & 3.34 & 1.95 & 0.98 & 99.99 \\
\hline 14 & 58.85 & 15.27 & 8.08 & 7.42 & 3.43 & 3.55 & 2.43 & 0.97 & 99.99 \\
\hline 15 & 60.76 & 15.19 & 7.06 & 7.25 & 2.72 & 3.91 & 2.35 & 0.75 & 99.99 \\
\hline 16 & 59.47 & 16.44 & 7.51 & 7.74 & 2.49 & 3.65 & 1.83 & 0.85 & 99.98 \\
\hline 17 & 58.19 & 16 & 7.99 & 8.13 & 3.07 & 3.55 & 2.2 & 0.9 & 100.03 \\
\hline 18 & 58 & 16.82 & 7.9 & 8.05 & 3.02 & 3.4 & 2.06 & 0.75 & 99.98 \\
\hline $19 \mathrm{~A}$ & 59.58 & 15.61 & 7.06 & 7.88 & 3.28 & 3.64 & 2.25 & 0.68 & 99.99 \\
\hline 20 & 60.35 & 15.53 & 7.2 & 7.39 & 2.55 & 3.75 & 2.52 & 0.68 & 99.98 \\
\hline 21 & 59.6 & 15.36 & 7.6 & 7.72 & 3.18 & 3.56 & 2.14 & 0.82 & 99.99 \\
\hline $21 \mathrm{~A}$ & 58.77 & 16.14 & 8.3 & 8.3 & 2.72 & 2.82 & 2.22 & 0.78 & 100.03 \\
\hline 25 & 59.07 & 16.06 & 8.32 & 8.6 & 2.24 & 2.57 & 2.29 & 0.83 & 99.99 \\
\hline 27 & 59.15 & 15.98 & 8.5 & 8.41 & 2.21 & 2.83 & 2.2 & 0.75 & 100.04 \\
\hline 28 & 59.62 & 16.17 & 8.48 & 8.33 & 2.11 & 2.31 & 2.36 & 0.67 & 100.04 \\
\hline 29 & 60.03 & 16.5 & 7.29 & 8.09 & 2.12 & 2.74 & 2.54 & 0.68 & 99.99 \\
\hline
\end{tabular}

and its highest relative proportion occurs in 2006 ash samples, though it was also found in 2008, 2010, 2011, and 2012 samples. The magnetite is in the range from 1 to $3 \%$ (3\% in the 2012 ash).

\section{Discussion}

\subsection{Eruption mechanisms and style transition between 1999-2013}

\subsubsection{Phase I}

The vent-cleaning phase of reawakening at Tungurahua in 1999 (Ruiz et al., 2006; Le Pennec et al., 2012) was recorded within the first tephra fall sample (October 1999) which involved a notable proportion of hydrothermally altered scoria $(30 \%)$ and small amounts $(5 \%)$ of glass shards. The recognizance of hydrothermal alteration at juvenile particles is a good tool to assess the existence of juvenile material recycling (e.g., Houghton and Smith, 1993). These particles are expected to contribute little, if any, thermal energy to the explosions (Hougton and Carey, 2015). The jagged perimeter of some of these particles indicates a brittle fragmentation, thus probably of preexistent deposits. There were not observed particles with quenching cracks, commonly associated to the fast passage (a few milliseconds) of newly fragmented particles through a domain of liquid water (Büttner et al., 1999), thus a phreatomagmatic origin is unlikely. However, there are inherent limitations of particle observation associated to the grain size fractions here studied, thus that phreatomagmatic should not be totally discarded, and both lithologic and textural patterns here observed have been frequently associated to the initial phreatic-phreatomagmatic transitional stages of volcano reawakening, such 

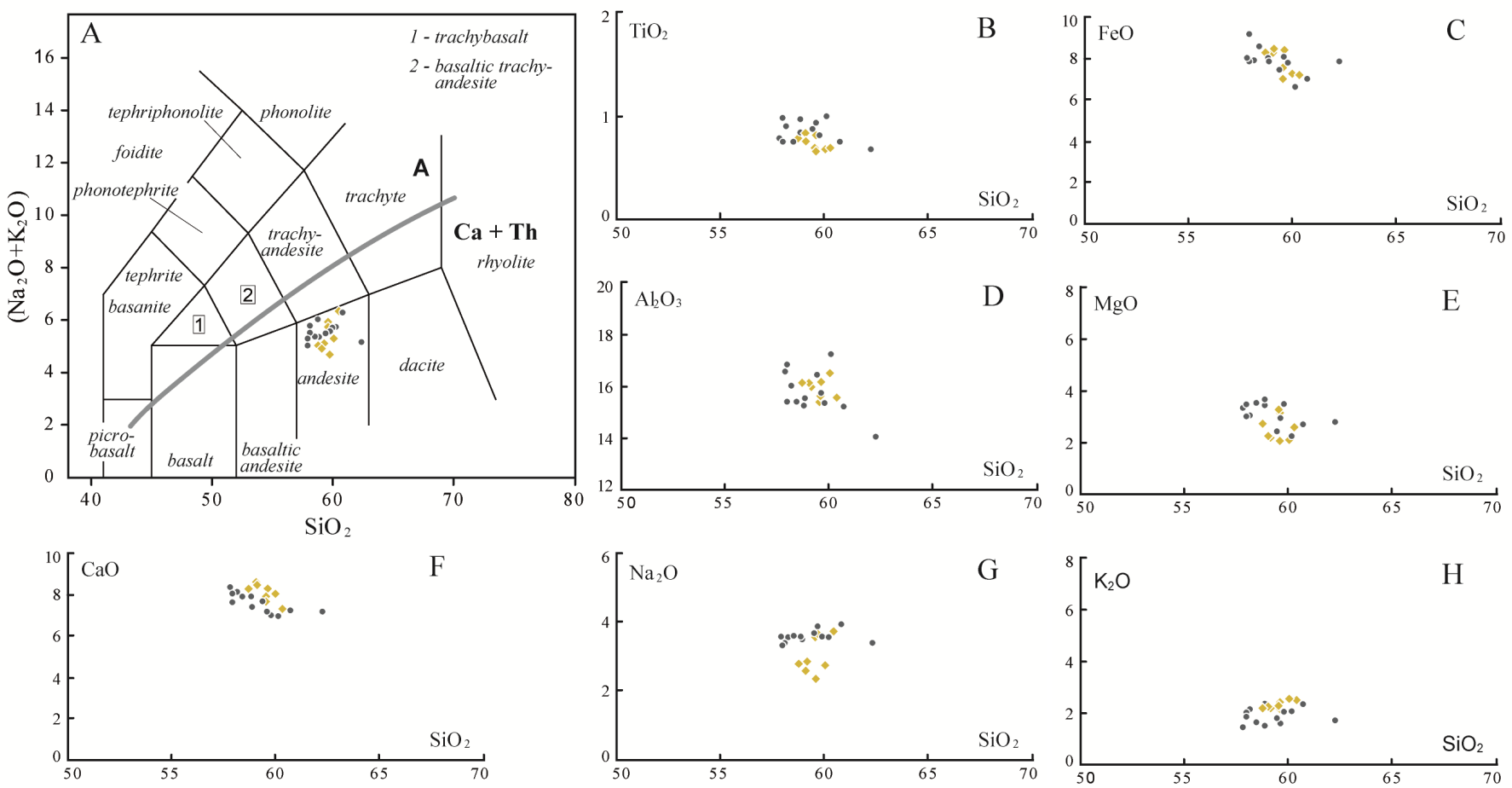

FIG. 7. Major element geochemistry of juvenile ash fragments for samples from Tungurahua volcano. A. TAS diagram of Le Maitre (1984). B-H. Harker diagrams, and I-K. variation diagrams.

In A: A alkaline, $\mathrm{Ca}+\mathrm{T}$ Calcoalkaline+Tholeiitic; In K: FM Ferromagnesian minerals (Fe-Mn-Mg), An Anorthite, Or Orthoclase.
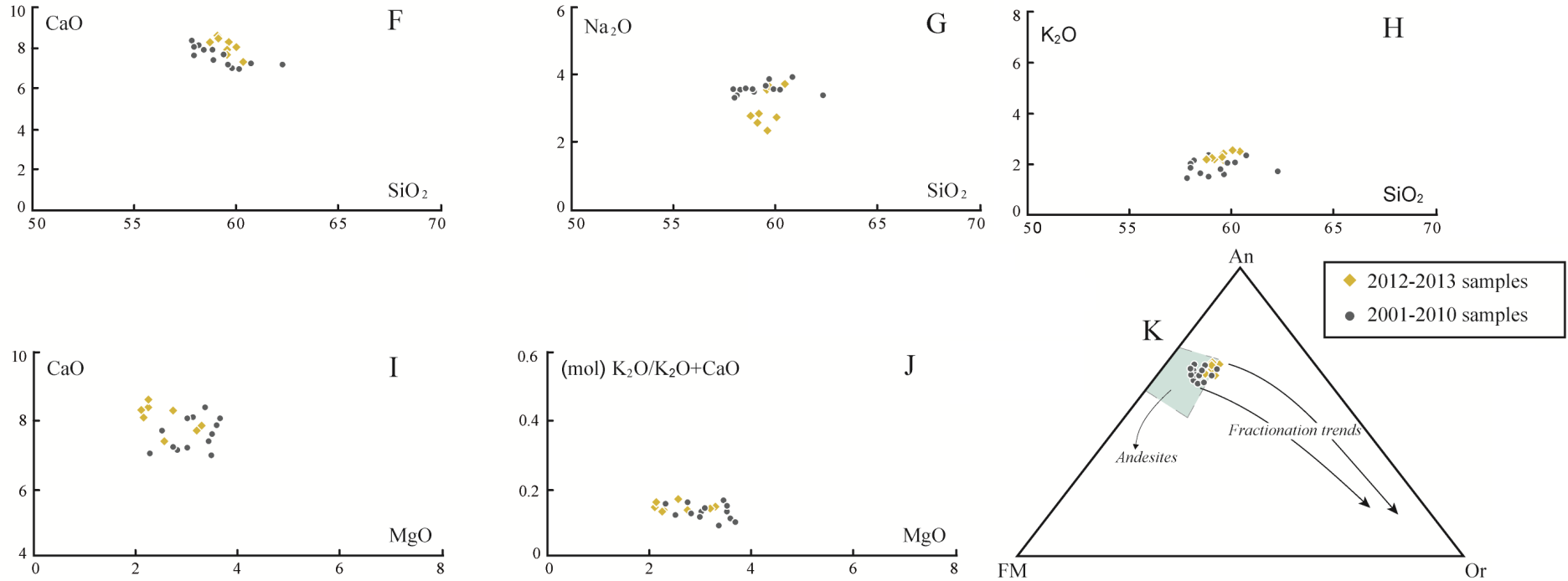
TABLE 5. MINERALOGICAL COMPOSITION OF ASH SAMPLES COLLECTED BETWEEN 1999 AND 2013 AT TUNGURAHUA VOLCANO. ALL THE ABUNDANCES ARE MODAL\%.

\begin{tabular}{|c|c|c|c|c|c|c|c|c|c|c|c|c|c|}
\hline \multirow[b]{3}{*}{$\begin{array}{l}\text { Mineral } \\
\text { Formula }\end{array}$} & \multicolumn{13}{|c|}{ Mineral, \% abundance } \\
\hline & \multicolumn{4}{|c|}{ Plagioclase group } & \multicolumn{5}{|c|}{ Pyroxene group } & \multicolumn{4}{|c|}{ Other } \\
\hline & $\begin{array}{c}\text { Anortite } \\
\mathrm{CaAl}_{2} \mathrm{Si}_{2} \mathrm{O}_{8}\end{array}$ & $\begin{array}{c}\text { Andesine } \\
(\mathrm{Na}, \mathrm{Ca}) \\
(\mathrm{Al}, \mathrm{Si})_{2} \mathrm{Si}_{2} \mathrm{O}_{8}\end{array}$ & $\begin{array}{c}\text { Albite } \\
\mathrm{NaAISi}_{3} \mathrm{O}_{8}\end{array}$ & Amount & $\begin{array}{c}\text { Diopside } \\
\mathrm{Ca}(\mathrm{Mg}, \mathrm{Al}) \\
(\mathrm{Si}, \mathrm{Al})_{2} \mathrm{O}_{6}\end{array}$ & $\begin{array}{c}\text { Pigeonite } \\
(\mathrm{Mg}, \mathrm{Fe}, \mathrm{Ca}) \\
\mathrm{SiO}_{3} \\
\end{array}$ & $\begin{array}{l}\text { Hedenbergite } \\
\mathrm{CaFeSi}_{2} \mathrm{O}_{6}\end{array}$ & $\begin{array}{l}\text { Enstatite } \\
\mathrm{MgSiO}_{3}\end{array}$ & Amount & $\begin{array}{c}\text { Olivine } \\
(\mathrm{Mg}, \mathrm{Fe})_{2} \mathrm{SiO}_{4}\end{array}$ & $\begin{array}{l}\text { Akermanite } \\
\mathrm{Ca}_{2} \mathrm{MgSi}_{2} \mathrm{O}_{7}\end{array}$ & $\begin{array}{c}\text { Magnetite } \\
\mathrm{Fe}_{3} \mathrm{O}_{4}\end{array}$ & Total \\
\hline 1 & 25 & 18 & 16 & 59 & 14 & 15 & - & 8 & 37 & 4 & - & - & 100 \\
\hline 2 & 24 & 17 & 16 & 57 & 12 & 16 & - & 10 & 38 & 5 & - & - & 100 \\
\hline 3 & 24 & 16 & 14 & 54 & 16 & 15 & 1 & 12 & 44 & 2 & - & - & 100 \\
\hline 4 & 21 & 15 & 17 & 53 & 14 & 18 & 1 & 9 & 42 & 5 & - & - & 100 \\
\hline 5 & 24 & 17 & 15 & 56 & 15 & 15 & - & 11 & 41 & 3 & - & - & 100 \\
\hline 6 & 25 & 15 & 14 & 54 & 20 & 7 & 1 & 16 & 44 & 2 & - & - & 100 \\
\hline 7 & 20 & 21 & 12 & 53 & 15 & 16 & - & 7 & 38 & 9 & - & - & 100 \\
\hline 8 & 22 & 17 & 18 & 57 & 18 & 16 & 1 & 6 & 41 & 2 & - & - & 100 \\
\hline $8 \mathrm{~A}$ & 26 & 18 & 20 & 64 & 11 & 18 & 1 & 3 & 33 & 3 & - & - & 100 \\
\hline 9 & 25 & 22 & 15 & 62 & 15 & 14 & - & 4 & 33 & 3 & 2 & - & 100 \\
\hline $9 \mathrm{~A}$ & 25 & 18 & 20 & 63 & 9 & 18 & 2 & 3 & 32 & 2 & 2 & 1 & 100 \\
\hline $9 \mathrm{~B}$ & 31 & 16 & 18 & 65 & 12 & 14 & 1 & 6 & 33 & - & 1 & 1 & 100 \\
\hline 10 & 25 & 21 & 12 & 58 & 14 & 12 & 2 & 9 & 37 & 5 & - & - & 100 \\
\hline 11 & 27 & 19 & 9 & 55 & 15 & 17 & 1 & 6 & 39 & 5 & - & 1 & 100 \\
\hline 12 & 23 & 16 & 17 & 56 & 14 & 15 & 2 & 7 & 38 & 4 & 1 & 1 & 100 \\
\hline 13 & 27 & 13 & 18 & 58 & 11 & 15 & 2 & 8 & 36 & 3 & 2 & 1 & 100 \\
\hline 14 & 28 & 15 & 15 & 58 & 12 & 16 & 3 & 7 & 38 & 3 & - & 1 & 100 \\
\hline 15 & 23 & 15 & 21 & 59 & 13 & 15 & 2 & 6 & 36 & 4 & 1 & - & 100 \\
\hline 16 & 23 & 20 & 17 & 60 & 12 & 16 & - & 8 & 36 & 2 & 2 & - & 100 \\
\hline 17 & 23 & 20 & 16 & 59 & 15 & 12 & 2 & 6 & 35 & 4 & - & 2 & 100 \\
\hline 18 & 28 & 18 & 16 & 62 & 11 & 16 & 2 & 5 & 34 & 4 & - & - & 100 \\
\hline $18 \mathrm{I}$ & 25 & 19 & 17 & 61 & 14 & 12 & 3 & 5 & 34 & 4 & - & 1 & 100 \\
\hline $18 \mathrm{~A}$ & 16 & 19 & 25 & 60 & 10 & 17 & 2 & 9 & 38 & 2 & - & - & 100 \\
\hline $18 \mathrm{~B}$ & 26 & 16 & 16 & 58 & 15 & 12 & 2 & 9 & 38 & 3 & 1 & - & 100 \\
\hline
\end{tabular}


table 5 continued.

\begin{tabular}{|c|c|c|c|c|c|c|c|c|c|c|c|c|c|}
\hline \multirow[b]{3}{*}{$\begin{array}{l}\text { Mineral } \\
\text { Formula }\end{array}$} & \multicolumn{13}{|c|}{ Mineral, $\%$ abundance } \\
\hline & \multicolumn{4}{|c|}{ Plagioclase group } & \multicolumn{5}{|c|}{ Pyroxene group } & \multicolumn{4}{|c|}{ Other } \\
\hline & $\begin{array}{c}\text { Anortite } \\
\mathrm{CaAl}_{2} \mathrm{Si}_{2} \mathrm{O}_{8}\end{array}$ & $\begin{array}{c}\text { Andesine } \\
(\mathrm{Na}, \mathrm{Ca}) \\
(\mathrm{Al}, \mathrm{Si})_{2} \mathrm{Si}_{2} \mathrm{O}_{8}\end{array}$ & $\begin{array}{c}\text { Albite } \\
\mathrm{NaAISi}_{3} \mathrm{O}_{8}\end{array}$ & Amount & $\begin{array}{c}\text { Diopside } \\
\mathrm{Ca}(\mathrm{Mg}, \mathrm{Al}) \\
(\mathrm{Si}, \mathrm{Al})_{2} \mathrm{O}_{6} \\
\end{array}$ & $\begin{array}{c}\text { Pigeonite } \\
(\mathrm{Mg}, \mathrm{Fe}, \mathrm{Ca}) \\
\mathrm{SiO}_{3}\end{array}$ & $\begin{array}{l}\text { Hedenbergite } \\
\mathrm{CaFeSi}_{2} \mathrm{O}_{6}\end{array}$ & $\begin{array}{l}\text { Enstatite } \\
\mathrm{MgSiO}_{3}\end{array}$ & Amount & $\begin{array}{c}\text { Olivine } \\
(\mathrm{Mg}, \mathrm{Fe})_{2} \mathrm{SiO}_{4}\end{array}$ & $\begin{array}{l}\text { Akermanite } \\
\mathrm{Ca}_{2} \mathrm{MgSi}_{2} \mathrm{O}_{7}\end{array}$ & $\begin{array}{l}\text { Magnetite } \\
\qquad \mathrm{Fe}_{3} \mathrm{O}_{4}\end{array}$ & Total \\
\hline $19 \mathrm{~A}$ & 28 & 16 & 12 & 56 & 12 & 18 & 3 & 4 & 37 & 5 & 2 & - & 100 \\
\hline 19 & 19 & 17 & 18 & 54 & 15 & 11 & 3 & 11 & 40 & 2 & 1 & 3 & 100 \\
\hline 19B & 29 & 20 & 15 & 64 & 19 & 7 & 2 & 5 & 33 & 2 & 1 & - & 100 \\
\hline $19 \mathrm{C}$ & 27 & 19 & 14 & 60 & 16 & 13 & 2 & 6 & 37 & 2 & - & 1 & 100 \\
\hline 19D & 17 & 18 & 23 & 58 & 23 & 5 & 2 & 7 & 37 & 3 & - & 2 & 100 \\
\hline $19 \mathrm{E}$ & 29 & 19 & 12 & 60 & 11 & 14 & 3 & 7 & 35 & 3 & 2 & - & 100 \\
\hline $19 \mathrm{~F}$ & 28 & 18 & 12 & 58 & 13 & 14 & 5 & 6 & 38 & 2 & 2 & - & 100 \\
\hline 20 & 31 & 18 & 14 & 63 & 14 & 7 & 2 & 7 & 30 & 5 & 1 & 1 & 100 \\
\hline $20 \mathrm{~A}$ & 22 & 23 & 13 & 58 & 14 & 17 & 2 & 4 & 37 & 4 & - & 1 & 100 \\
\hline 21 & 20 & 19 & 17 & 56 & 16 & 17 & 1 & 5 & 39 & 3 & - & 2 & 100 \\
\hline $21 \mathrm{~A}$ & 28 & 22 & 6 & 56 & 15 & 18 & 1 & 7 & 41 & 2 & - & 1 & 100 \\
\hline 22 & 23 & 14 & 23 & 60 & 22 & 6 & 1 & 6 & 35 & 2 & 1 & 2 & 100 \\
\hline 23 & 27 & 18 & 13 & 58 & 12 & 20 & 3 & 4 & 39 & 2 & 1 & - & 100 \\
\hline 24 & 28 & 15 & 20 & 63 & 11 & 9 & 1 & 9 & 30 & 5 & 1 & 1 & 100 \\
\hline 25 & 23 & 20 & 15 & 58 & 9 & 13 & 3 & 8 & 33 & 5 & 2 & 2 & 100 \\
\hline 26 & 24 & 18 & 17 & 59 & 17 & 11 & 3 & 8 & 39 & 2 & - & - & 100 \\
\hline 27 & 23 & 19 & 13 & 55 & 21 & 14 & 2 & 5 & 42 & 3 & - & - & 100 \\
\hline 28 & 20 & 16 & 18 & 54 & 16 & 12 & 3 & 7 & 38 & 5 & 1 & 2 & 100 \\
\hline 29 & 27 & 18 & 15 & 60 & 12 & 15 & 3 & 7 & 37 & 2 & 1 & - & 100 \\
\hline
\end{tabular}


as the case of Cotopaxi in 2015 (e.g., Gaunt et al., 2016; Troncoso et al., 2017). The disappearance of altered scoria in the samples collected in July 2000, and the increasing participation of glass shards, scoria and microcrystalline lithics is attributed to the rising of the magma to the surface and its progressive eruption through an open-vent system. In consequence, the onset of Phase I is related to the progressive cleaning of the vent due to rising of a renewed magma which was finally erupted since 2001 with an open-vent style (Fig. 8A and B). The low vesicularity and blocky shape of the juvenile fragments has been suggested by Cioni et al. (2014) as consequence of the shuttering of syn-eruptively degassed, crystallized, more rigid and volatile-rich magmas explosively fragmented, as it was observed during the 2010 Eyjafjallajökull eruption.

Further tephra emissions in 2002 and 2003 were produced by Strombolian and Vulcanian-like eruptions consisted of two varieties of juvenile scoria (black and brown) accompanied by higher amounts of glass shards (10-15\%) which is consistent with an open vent system. The two different types of scoria ejected may be attributed to textural variations (such as crystallinity/ vesicularity) or to the eruption of an heterogeneous melt (i.e., magma mingling or an stratified magma column). However, the bulk ash geochemistry of these samples was quite stable (57.9-60.2 $\mathrm{wt} \%$ $\mathrm{SiO}_{2}$ ), similarly to the mineral phases identified via XRD (Table 5). This geochemical and mineralogical stability may be explained by the eruption of juvenile particles with different vesicularity and groundmass crystal content, which may suggest the fragmentation of a vertically heterogeneous magma column (Cioni et al., 2014), or as result of varying magma supply rates as demonstrated by Wright et al., (2012) within this period (Fig. 8B). From textural observations, can be suggested that both rheology and magma supply rates favor this juvenile textural bimodalities.

\subsubsection{Phase II}

The largest eruptions during 2006 showed long-lasting unrest periods in the months prior to the eruption (e.g., Champenois et al., 2014). There occurred a progressive decrease of black scoria in time, whereas the brown scoria increased. As previously suggested, these bimodal juvenile particles may be correlated to the stratification of the magma column in the conduit. This agrees with the increasing vesicularity of juvenile grains between April and August 2006, which suggest the progressive eruption of a volatile-saturated magma. In fact, for a given viscosity, increasing density of bubbles correlates with higher bubble nucleation rates that have been attributed to progressively later onset of bubble nucleation at higher degrees of supersaturation with volatiles (Houghton and Carey, 2015). Thus, the predominance of highly vesicular fragments suggests a prominent and active role of degassing-related magmatic fragmentation during the eruption (Cioni et al., 2014). An additional fact is the shape of these vesicles. Elongated and fibrous vesicles, such as these observed in the 24 August samples are indicative of magma fragmentation due to a rapid acceleration of the system (Cashman et al., 2000) or as representative of the central part of a magmatic column at the conduit during Pliniantype eruptions, where vesicles are free to grow only subjected to elongational stresses (Polacci, 2005). All these observations are coherent with the direct observations of the volcanic activity during 2006, which produced a stratospheric column (Fig. 8C). However, in contrast to the geochemical data obtained from samples collected from the rest of the time series, the bulk rock geochemistry at August 2006 reveals a silica-rich andesitic composition $\left(62.3 \mathrm{wt} \% \mathrm{SiO}_{2}\right)$. Additional changes are noticed from mineralogy by the first recognizance of akermanite and magnetite, higher amounts of plagioclase $(>60 \%)$ and lower amounts of pyroxene (32-33\%) together permanent olivine, all of them recognized via XRD as characteristic for this period. Thus, the compositional heterogeneity should indicate mixing of two magmas (Fig. 8C). This is in agreement with the observations made by several authors (e.g., Fee et al., 2010; Steffke et al., 2010; Samaniego et al., 2011; Eychenne et al., 2013; Myers et al., 2014). In fact, melt inclusion composition paired with host phenocryst zonation made by Myers et al. (2014) indicated mixing of two distinct magmas: a volatilerich $\left(\sim 4.0 \mathrm{wt} \% \mathrm{H}_{2} \mathrm{O}\right.$ and $\left.\sim 1,800 \mathrm{ppm} \mathrm{S}\right)$ basaltic andesite containing olivine phenocrysts and a degassed $\left(\sim 1.0 \mathrm{wt} \% \mathrm{H}_{2} \mathrm{O}\right.$ and $\left.100-500 \mathrm{ppm} \mathrm{S}\right)$ andesite with plagioclase and pyroxene phenocrysts that contain andesitic to dacitic melt inclusions.

\subsubsection{Phase III}

During the initial stage of Phase III in 2007, there was a new increase of hydrothermally altered reddish scoria and lithics (total amount 40-65\%), 
A. Early Phase I

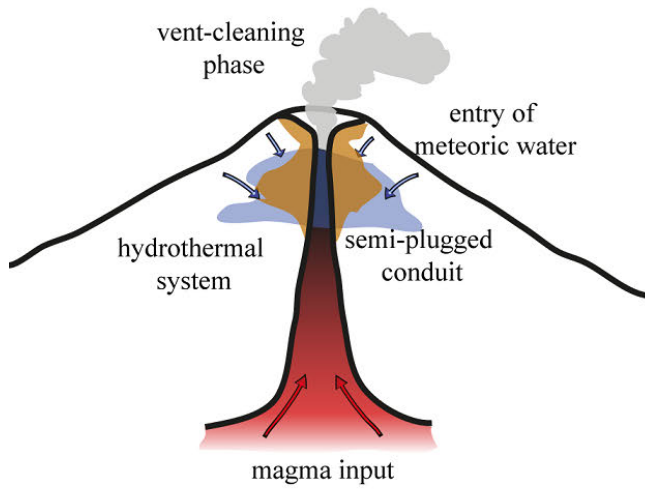

C. Phase II

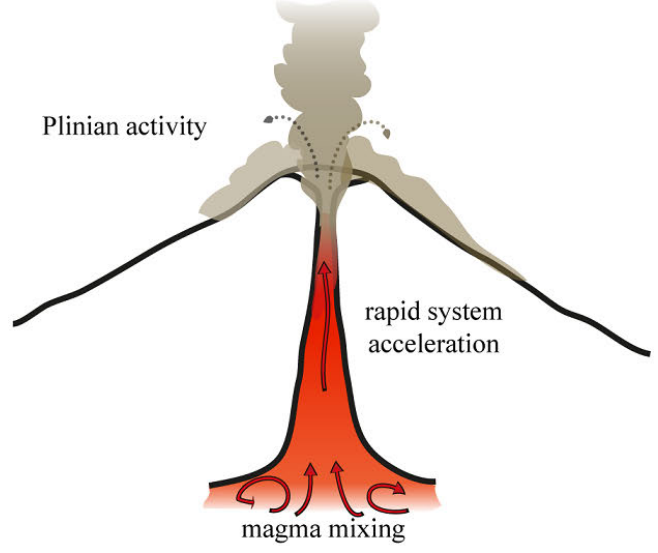

B. Late Phase I - Late Phase III - Half Phase IV

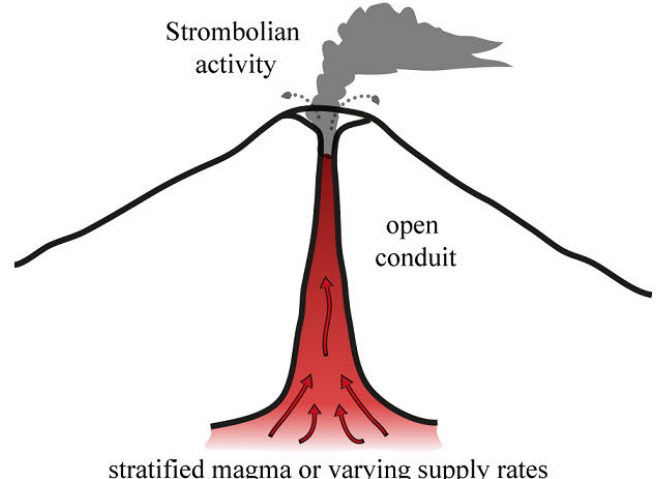

D. Early Phase III - Late Phase IV

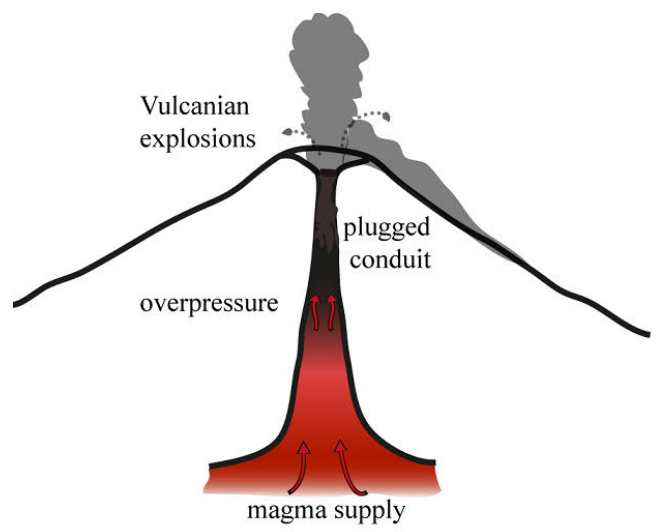

E. Phase IV - eruptive silence periods

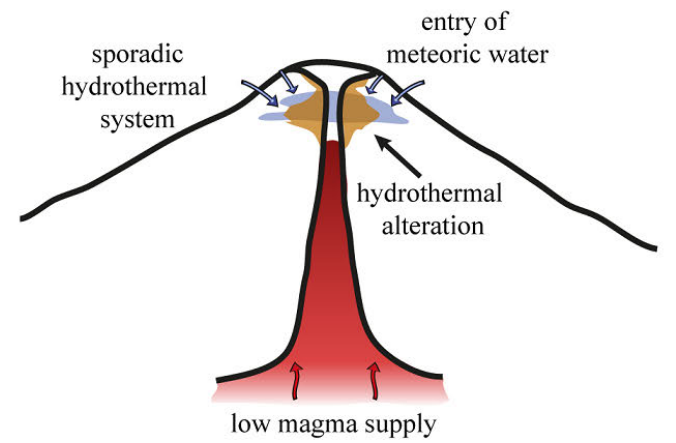

FIG. 8. Cartoons of the different eruption mechanisms operating in Tungurahua volcano between 1999 and 2013. A. Model of the early Phase I with the development of an initial phreatic eruption. Rising magma transfers heat to the hydrothermal system producing the eruption of recycled rocks, including hydrothermally altered wall rocks; B. Open conduit dynamics as observed in late phase I, late Phase III and partially in Phase IV. Varying magma supply rates or stratified conduit determines the transition between brittle and ductile fragmentation, producing juvenile particles with varying degree of vesicularity and variable shape; C. Magma mixing produces a volatile-saturated melt which triggers Plinian activity during Phase II; D. A decrease of magma supply rates may contribute to the plugging of the conduit and the over-pressurization of the magma column to trigger Vulcanian eruptions as in early Phase III and late Phase IV; E. Similarly to A, during eruptive silence periods in Phase IV the entry of meteoric water favored the formation of an sporadic hydrothermal system and local wall-rock hydrothermal alteration. Low magma supply was not able to trigger eruptions. 
reaching similar proportions to juvenile particles (black scoria, free crystals and glass shards). There are not textural indicators of phreatomagmatic interactions in juvenile particles (there were only observed particles with blocky and fluid shapes), however the hydrothermal alteration, the amount of recycled material and the existence of fresh juvenile particles suggest a Vulcanian mechanism (Fig. 8D). For comparison, during the $1^{\text {st }}$ February 2014 Tungurahua eruption, an average of $49.34 \%$ corresponded to non-juvenile material in tephra (38.16\% lithics and $11.18 \%$ altered scoria), thus a minimum limit of $40 \%$ of recycled material will be here considered as indicative of Vulcanian eruptions.

Several fluid, filamentous and blocky shaped glassy particles were identified within the ashes of 5-6 February 2008. Melt droplets, preserved as fluidal clasts (filaments) are correlated to magmas that fragment in a hot fluid state (Houghton and Carey, 2015). These particles are most typically associated with small subaerial explosive eruptions of low-viscosity $\left(<10^{2} \mathrm{~Pa} \mathrm{~s}\right)$ basaltic melts, due to the deformation of low-viscosity lava in the air (Moune et al., 2007). Thus, we can associate these particles to the alternation between ductile and brittle fragmentation of a hot magma, as result of varying rheology and/or sypply rate of the magma, similarly to Phase I. This agrees with the direct observation of alternating episodes of jetting and explosions (Biggs et al., 2010).

The short-to medium-lived eruptions occurred since 2008, which erupted exclusively blocky juvenile material with low-to-moderate vesicularities is typical from Strombolian eruptions, and reflects the brittle fragmentation of volatile loaded magma (Fig. 8B).

\subsubsection{Phase IV}

Hydrothermally altered fragments, represented by reddish scoria was frequent in most of the samples since 2010 up to 2012, but always at lower amount than 30\%, much lower than in Phase III. These tephras enriched in altered fragments were interspersed with some infrequent, purely juvenile tephras and a particular tephra fall full of lithics in December $27^{\text {th }}$ 2011. At surface level, Vulcanian eruptions with little geophysical warning are inferred from eyewitness observations within this period and also in the following years (e.g., Hall et al., 2015; Mothes et al., 2015; Parra et al., 2015; Kim et al., 2014; Romero et al., 2017). However, Vulcanian events are characterized by a series of physical properties and distinguishable eruptive products (e.g., Clarke et al., 2015; Morrisey and Mastin, 2000) such as $>40 \%$ of recycled particles within tephra, as we previously established for Tungurahua (Phase III and $1^{\text {st }}$ February 2014) which was not observed between 2010 and 2012, with the only exception of the December 2012 event. In addition, vesicularity of juvenile particles was zero or moderate-to-high, not spanning a wide range as frequently observed during Vulcanian eruptions (e.g., Clarke et al., 2015). These particles also exhibited ductile fragmentation features such as fluid and filamentous shapes, despite fewer blocky shapes were observed. Pure magmatic dynamics, especially during Strombolian activity is more prone to produce these particles (Fig. 8B). This is also supported by the eruption of dominant pumice in 2013. Thus, at this point the origin of hydrothermally altered grains remains unclear. Then, was Tungurahua able to develop an active hydrothermal system (necessary condition to provide hydrothermally altered particles) during the paucity of magmatic eruptions?. Even when the heat transfer from shallow magma batches is not favorable for the existence of an hydrothermal system, the development of a reduced or sporadic hydrothermal system is possible, as indicated by geochemical and isotopic characterization of springs and bubbling waters sampled at Tungurahua, which are $\mathrm{Cl}-\mathrm{SO}_{4}$ earth-alkaline, medium salinity and significant He-mantle signature (around 60\%) fluids (Inguaggiato et al., 2010). Thus, the lesser amounts of hydrothermally altered particles between 2010 and 2013 are likely related to a harder involvement of water in the system during the non-eruptive stages, and not to conduit plugging. This condition was favored by the episodic frequency of eruptions, which permitted the infiltration of meteoric water into the conduit (Fig. 8E). Even more, the episodic frequency of these eruptions was probably not associated to the conduit plugging, but yet correlated to a change in the magma supply rate or an increase in the viscosity of magma intrusions. This is well constrained with the geochemical variations observed in the year 20122013 which may be interpreted as the intrusion of a "renewed" (deeper, volatile-rich magma) triggering magma mixing and eruption, as it is also noticed by Myers et al. (2014) in 2010. Even though a single Vulcanian eruption is identified using tephra between 2010 and 2013, further eruptions at the end of 
Phase IV (2013-2014) were well recognized as Vulcanian (e.g., Hall et al., 2015; Parra et al., 2015; Romero et al., 2017). The transition in time from open to a plugged conduit suggest a progressive decrease of the magmatic ascent rates or the increase in magma viscosity through time.

\subsection{Magmatic processes feeding eruptive transitions}

Within its geological and historical eruptive history, Tungurahua products range from basaltic andesites to dacites, with subordinate rhyolites, and a typical plg $+\mathrm{cpx}+\mathrm{opx} \pm \mathrm{hbl} \pm \mathrm{ol} \pm \mathrm{Fe}$-Ti oxides mineral assemblage (Hall et al., 1999; Bustillos, 2008; Samaniego et al., 2011). The rock compositions from ancient and modern Tungurahua edifices (I, II and III) (Hall et al., 1999; Bustillos et al., 2011) turn out to be similar to the composition of tephra emitted between 1999 and 2013, as they are both medium- to high-K andesites (54-58 wt $\left.\% \mathrm{SiO}_{2}\right)$. If we assume that analytical issues are avoided during the sampling and analytical processes, the absence of linear trends in variation diagrams and the separation between the 2012-2013 and the rest of the samples may be related to different temperature, pressure and/ or water content conditions at the source of these magmas and reject a differentiation or fractionation process from a similar magmatic source. This could be complementary to that proposed by Myers et al. (2014) on the co-existance of several magma reservoirs at different depth (shallow, 1-3 km under the base of the volcano and a deep reservoir at $>7 \mathrm{~km}$ depth).

\subsection{Tephra GSD}

\subsubsection{Depositional processes inferred}

According to Eychenne et al. (2012), the eruption of August 2006 at Tungurahua had bimodal GSD deposits controlled by two synchronous processes: lapilli deposition from the main plume and fine ash elutriated from PDCs. This situation was also shown by Bernard et al. (2016). At least 5 eruptive phases produced PDCs from 2007 to 2013 (March 2007, February 2008, May and December 2010, December 2012, May and July 2013) (Hall et al., 2015; Bustillos et al., 2016), which is in good agreement with the increase of bimodal and trimodal GSDs from 2009 to 2013. For example, the major eruption occurred in May $28^{\text {th }} 2010$, which produced an eruption column of $10 \mathrm{~km}$ above the crater level (a.c.l.) and a series of PDCs, corresponds to deposits with bimodal GSD characterized by two opposite modes at fine lapilli $(-0.74 \Phi)$ and very fine ash $(4.23 \Phi)$ (Table 3). These features are not unique for purely-magmatic, large scale eruptions, as they are also observed in moderate Vulcanian eruptions occurred later in 2013 and 2014 (e.g., Parra et al., 2015; Romero et al., 2017).

Particle aggregation has been also associated with bimodal or polymodal GSDs in the literature (e.g., Scasso et al., 1994; Durant et al., 2009). We suggest that trimodal GSD in sample 18B is related to particle aggregation, as evidenced by the SEM analyses which show abundant aggregates that correspond to coated particles, bound by hydro-bonds and electrostatic forces, and in most cases are poorly preserved due to the particle impact during fall (particle type PC2 in Brown et al., 2012). As Tungurahua area annually receives a notable amount of rainfall (about $3000 \mathrm{~mm}$; Jones et al., 2015) we suspect that the humidity provided by these atmospheric processes could favor the formation of aggregates during explosive eruptions, especially when no phreatic eruptive mechanism is suspected through ash analyses. Although thunderstorms/lightning are not often reported in this area (e.g., Rollenbeck and Bendix, 2011) but they may occasionally promote the formation of aggregates. Nevertheless, these two explanations do not account for all the bimodal and trimodal deposits and should be considered as alternative mechanisms of ash aggregation in this area.

In the case of samples not generated during PDC-forming eruptions or ash aggregation, a third deposition mechanism is required. Possible explanations are: 1) the nature of Vulcanian events that may erupt both fine and coarse grained tephra including ballistic rocks (e.g., Fierstein et al., 1997; Cashman et al., 2000; Houghton et al., 2004; Clarke et al., 2015), which may be deposited together, especially in the proximal zones as our sampling stations; or 2) the plume dispersal patterns, including plume bifurcation, wind direction variability and deposition of long-lasting (tens of days) eruptions that produce millimeter-thick deposits with complex dispersals and non-elliptic isopachs (Bernard et al., 2013). This would generate modes with different, but not extreme grain sizes (i.e., very fine grained or very coarse grained), as seen in table 3 for all the samples prior to 2006.

We suggest that, during the first 7 years of eruptions (1999-2006), processes like plume bifurcation and 
sedimentation of multiple plumes were responsible of most polymodal GSD (Fig. 9A), while during and after 2006 there was a combination of deposition processes that generated bimodal/ trimodal GSD deposits, such as interaction between plume and
co-PDC deposition (Fig. 9B), Vulcanian fragmentation (Fig. 9B), and the variability of tephra plumes. As an accessory and marginal process, we suggest that ash aggregation could be produced during strong thunders or lighting in the area of Tungurahua (Fig. 9C).

\section{A}

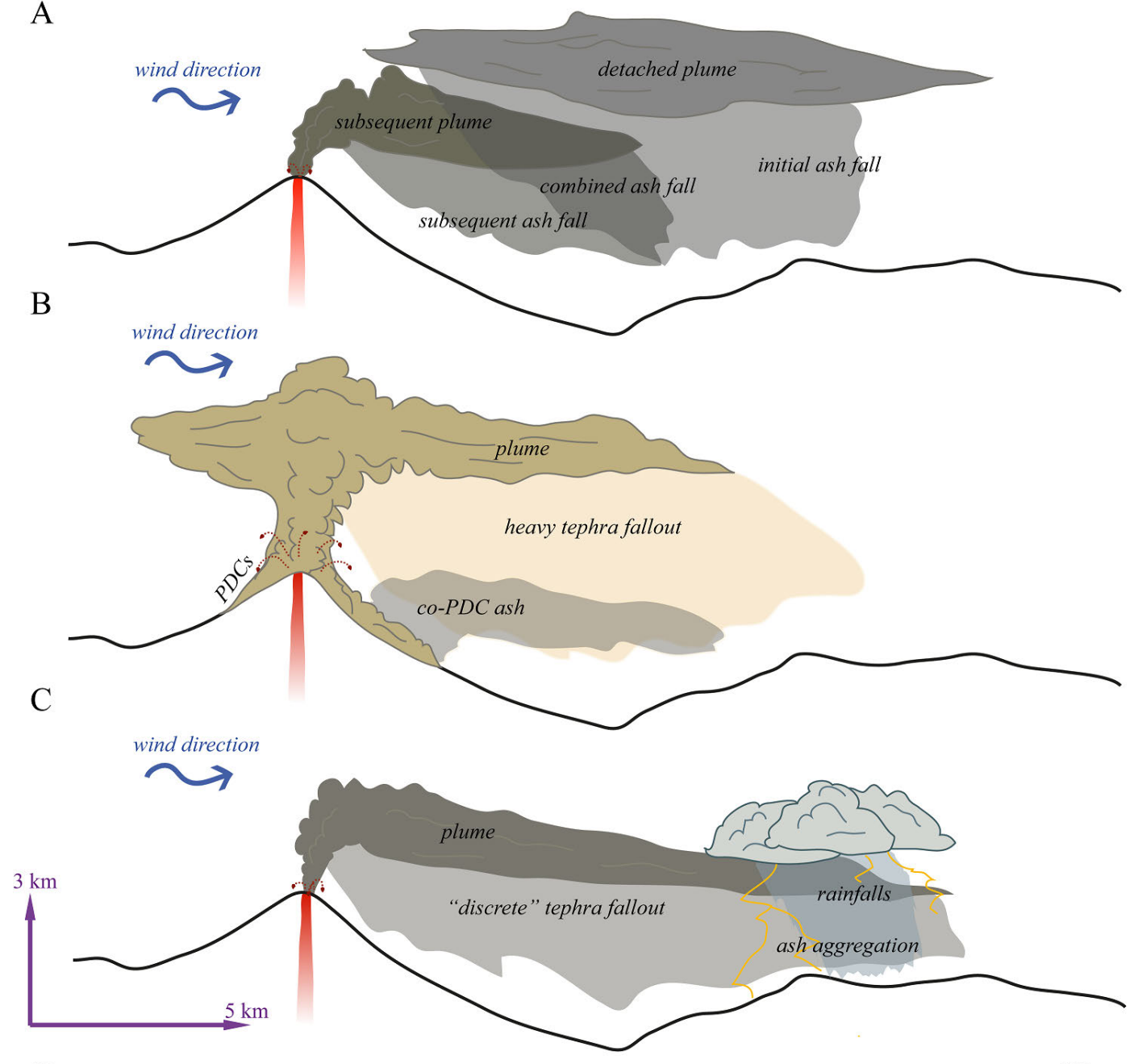

East

West

FIG. 9. Cartoons of the different fall out mechanisms proposed for tephra fall deposits at Tungurahua volcano. A. When no major eruptions or atmospheric anomalies are occurring, transitions in eruptive style (e.g., phreatic to Strombolian, Vulcanian to Strombolian or similar cases), produce variations in the dispersal pattern of tephra and spasmodic activity produce tephra deposits with polymodal GSD; B. Major eruptions (purely magmatic as in August 2006 or Vulcanian-triggered as in 28 May 2010 or 14 July 2013, VEI 3) may develop high eruptive columns ( $>10 \mathrm{~km}$; not to scale in figure) with "heavy" tephra fall, including lapilli-to bomb-sized fragments at $\sim 10 \mathrm{~km}$ radius from the vent, together with abundant ash. Pyroclastic density currents (PDCs) flowing down the flanks of the volcano might contribute fine material associated with co-PDC clouds. This was shown by Bernard et al. (2016) for the August 2006 eruption. Ballistics at a distance up to 4-5 km are common. The combination of all of those products may be responsible of polymodal GSD in tephra samples; C. During "weak" eruptions (VEI 1-2) atmospheric anomalies (i.e., rain fall and/or electrical storms) may induce particle coating leading to the formation of ash aggregates. In areas without these disruptions, tephra fall will probably produce unimodal or bimodal grain size distribution. 


\subsubsection{Potential health impacts}

Acute respiratory manifestations seen after heavy ash falls include irritation of the chest, nose and throat discomfort, but also acute exacerbations of asthma and bronchitis are seen (Gudmundsson, 2011). As shown in table 3, the extremely fine ash particle size, both thoracic and respirable (breathable) $(<10$ and $<4 \mu \mathrm{m}$, respectively) have been calculated using the method of Horwell and Baxter (2006). The average proportion of Tungurahua's respirable-sized ash is estimated at $\sim 5 \mathrm{wt} \%$ (range from 0.07 to $13.64 \mathrm{wt} \%$ ) nevertheless no crystalline silica (i.e., quartz, cristobalite or tridimite) has been identified via XRD. In addition, filamentous glassy particles (known for being abrasive; e.g., Horwell and Baxter, 2006) are always observed in larger sizes $(>200 \mu \mathrm{m})$ than for respirable or alveolar particles. Thus, the ash of Tungurahua has to be considered as potentially harmful for human health as a result of long-lasting exposure, especially because it may trigger acute health problems despite chronic diseases. This is in agreement with direct health observations, as epidemiological map has changed in the villages affected by the volcano while bronchial asthma, cough, throat irritation, eye irritation and respiratory allergies, and altered pulmonary capacity (spirometry) has been reported after Tungurahua ash exposure (Paladines and Zamora, 2011; Cifuentes and Alvarado, 2015)

\section{Conclusions}

Some conclusions derived from our research are listed below:

a. During the initial stage (1999-2000) of the current eruptive cycle at Tungurahua, a progressive conduit cleaning is observed as the eruption elapses. At the beginning of the eruption in 1999 phreatic mechanism has been interpreted, as no evidence of phreatomagmatic activity has been found using the current methods. The ashes then erupted in 2001 revealed the explosive fragmentation of a degassed, crystallized and "rigid" magma. In contrast, the juvenile products erupted after in 2002 and 2003 exhibited bimodal textures and compositional (chemistry and mineralogy) homogeneity, and we suggest they reflect variations in both magma supply rate and its rheology within a stratified magma column, without any evidence of the interaction between two different magma intrusions. b. The progressive variation of the 2006 Plinian eruption and associated tephra components, in addition to the textural changes observed in juvenile particles suggest that these eruptions were fed by a volatile-saturated magma, thus the fragmentation of magma occurred by its degassing and its rapid acceleration within the conduit. Even more, the evidence from geochemistry and mineral phases indicate a compositional change of the magma if compared to the pre-2006 series, which is in agreement with the previously reported mixing of two magmas (e.g., Samaniego et al., 2011; Myers et al., 2014).

c. During early 2007, the eruption of high amounts recycled particles (40-65\%) accompanied by juvenile particles are compatible with a series of Vulcanian eruptions. In contrast, the eruptions then occurred in 2008 were magmatic and ejected both fluid and brittle-fragmented juveniles during jetting periods and explosions. This is interpreted as a result of varying rheology and/or supply rate of the magma, similarly as seen in 2002-2003. The short-to medium-lived eruptions occurred since 2008 , ejected blocky juveniles as typically seen during Strombolian eruptions, and reflects the brittle fragmentation of volatile loaded magma.

d. Varying amounts of hydrothermally altered particles (always $<30 \%$ ) between 2010-2013 are likely related to a harder involvement of water in the system during the periods of eruptive silence, which certainly permitted the infiltration of meteoric water into the conduit. The textural features of juvenile particles suggest a dominant ductile fragmentation associated to Strombolian activity. Formal Vulcanian events are newly recognized in December 2011 and widely observed since 2013. The transition in time from open to plugged conduit dynamics suggest a progressive decrease of the magmatic ascent rates or the increase in magma viscosity through time.

e. From grain size analyses, we propose two first order phenomena during tephra deposition: 1) plume bifurcation and sedimentation of multiple plumes were responsible of most polymodal GSD, mainly occurring between 1999 and 2006; 2) deposits with bimodal/trimodal GSD as consequence of interaction between plume and co-PDC deposition (PDC elutriation), Vulcanian fragmentation, and the variability of tephra plumes during and after 2006; a second order factor could be ash 
aggregation during strong thunders or lighting in the area of Tungurahua.

f. Due to its mechanical properties, the ash of Tungurahua has to be considered as potentially harmful for human health as a result of long-lasting exposure, especially because it may trigger acute health problems despite chronic diseases. Not crystalline silica has been identified.

g. This study demonstrates that periodic and systematic tephra fall sampling at long-lasting erupting volcanoes is a valuable tool for understanding the eruptive mechanisms and the processes and impacts related to tephra falls, especially at inhabited areas.

\section{Acknowledgements}

This project contains partial results from the Ph.D. thesis of A. Guevara. Laboratory (XRF, XRD and SEM-EDS) analyses were supported by the DEMEX (Departamento de Metalurgia Extractiva) from Escuela Politécnica Nacional. We thank the fruitful comments of Dr. H. Delgado Granados (Universidad Autónoma de México) and Dr. F. Maeno (University of Tokio), plus the English review given by translator P. Soto. We acknowledge to the reviewers, Drs. H. Moreno Roa and D. Sellés by their very helpful comments which certainly improved this manuscript. Also, the editorial handling of Dr. W. Vivallo was essential.

\section{References}

Almeida, E.; Ramón, P. 1991. Las erupciones históricas del volcán Tungurahua. Boletín Geológico Ecuatoriano 2: 89-138.

Arellano, S.R.; Hall, M.; Samaniego, P.; Le Pennec, J-L.; Ruiz, A.; Molina, I.; Yepes, H. 2008. Degassing patterns of Tungurahua volcano (Ecuador) during the 1999-2006 eruptive period, inferred from remote spectroscopic measurements of $\mathrm{SO}_{2}$ emissions. Journal of Volcanology and Geothermal Research 176 (1): 151-162.

Aspden, J.; Jemielita, R.; Litherland, M.; Bermúdez, R.; Bolaños, J.; Pozo, M.; Viteri, F.; Celleri, M. 1994. Geological and Metal Occurrence maps of the Northern Cordillera Real, Metamorphic Belts, Ecuador. British Geological Survey 11. 1:500.000.

Bernard, B.; Bustillos, J.; Wade, B.; Hidalgo, S. 2013. Influence of the wind direction variability on the quantification of tephra fallouts: December 2012 and March 2013 Tungurahua eruptions. Avances en Ciencias e Ingenierías 5 (1): A14-A21.
Bernard, J.; Eychenne, J.; Le Pennec, J. L.; Narváez, D. 2016. Mass budget partitioning during explosive eruptions: insights from the 2006 paroxysm of Tungurahua volcano, Ecuador. Geochemistry, Geophysics, Geosystems 17 (8): 3224-3240.

Biggs, J.; Mothes, P.; Ruiz, M.; Amelung, F.; Dixon, T.H.; Baker, S.; Hong, S.-H. 2010. Stratovolcano growth by co-eruptive intrusion: The 2008 eruption of Tungurahua Ecuador. Geophysical Research Letters 37: L21302.

Blott, S.J.; Pye, K. 2001. Gradisat: A grain size distribution and statistics package for the analysis of unconsolidated sediments. Earth Surface Processes and Landforms 26: 1237-1248.

Bonadonna, C.; Macedonio, G.; Sparks, R.S.J. 2002. Numerical modeling of tephra fallout associated with dome collapse and Vulcanian explosions: application to Hazard assessment on Monserrat. In The eruption of Soufriere Hills Volcano, from 1995 to 1999 (Druitt, T. H.; Kokelaar , B.P.; editors). Geological Society, London, Memoirs 21: 517-537.

Brown, R.J.; Bonadonna, C.; Durant, A.J. 2012. A review of volcanic ash aggregation. Physics and Chemistry of the Earth 45-46: 65-78.

Büttner, R.; Dellino, P.; Zimanowski, B. 1999. Identifying magma-water interaction from the surface features of ash particles. Nature 401 (6754): $688 \mathrm{p}$.

Bustillos, J. 2008. Las Avalanchas de Escombros en el sector del volcán Tungurahua. Tesis de Grado (Inédito). Escuela Politécnica Nacional: 151 p.

Bustillos, J. 2010. Transición del estilo eruptivo durante las erupciones andesíticas en sistema abierto: Contribución al estudio de los depósitos de ceniza del volcán Tungurahua. Master Thesis (Inédito), Nice Sophia Antipolis University: 48 p. France.

Bustillos, J.; Mothes, P. 2010. Ash falls at Tungurahua volcano: implementation of systematic ash collection for quantifying accumulated volumes. Cities On Volcanoes, No. 6, abstract volume: 2.7-O-07. Tenerife, Canary Island, Spain.

Bustillos, J.; Ruiz, G.; Le Pennec, J. 2011. Volcán Tungurahua: Cálculo indirecto del material sólido emitido. In Jornadas en Ciencias de la Tierra, No. 7, Equator Meetings S.A., ISBN: 978-9978-383-17-9. Quito.

Bustillos, J.; Guevara, A.; Hidalgo, S. 2013. Los depósitos de ceniza del 04 y 05 de Mayo 2013 en el volcán Tungurahua. Pyroclastic Flow 3 (1): 1-8.

Bustillos, J.; Romero, J.; Troncoso, L.; Guevara, A. 2016. Tephra fall at Tungurahua Volcano (Ecuador)-1999-2014: An example of tephra accumulation from a long-lasting eruptive cycle. Geofísica Internacional 55 (1): 363-386. 
Cannata, C.B.; De Rosa, R.; Donato, P.; Taddeucci, J. 2014. Ash Features from Ordinary Activity at Stromboli Volcano. International Journal of Geosciences 5: 1361-1382.

Carey, S.; Sigurdsson, H. 1982. Influence of particle aggregation on deposition of distal tephra from the May 18, 1980 eruption of Mount St. Helens volcano. Journal of Geophysical Research 87: 7061-7072.

Cas, R.A.F.; Wright, J.V. 1987. Volcanic successions: Modern and ancient: a geological approach to processes. Allen and Union: 528 p. London.

Cashman, K.V.; Sturtevant, B.; Papale, P.; Navon. 2000. Magmatic Fragmentation. In Encyclopedia of Volcanoes (Sigurdsson, H.; Houghton, B.; Rymer, H.; Stix, J.; McNutt, S.; editors). Academic Press: 1417 p.

Castro, A. 2013. Tonalite-granodiorite suites as cotectic systems: a review of experimental studies with application to granitoid petrogenesis. Earth-Science Reviews 124: 68-95.

Champenois, J.; Pinel, V.; Baize, S.; Audin, L.; Jomard, H.; Hooper, A.; Alvarado, A.; Yepes, H. 2014. Large-scale inflation of Tungurahua volcano (Ecuador) revealed by Persistent Scatterers SAR interferometry. Geophysical Research Letters 41 (16): 5821-5828.

Cifuentes, A.C.; Alvarado, L.A. 2015. Efecto en la salud respiratoria de las comunidades de Pillate, Manzano y Chonglontus expuestas crónicamente a la inhalación de ceniza del volcán Tungurahua. Tesis (Inédito). Universidad de las Américas: 47 p.

Cioni, R.; D’Oriano, C.; Bertagnini, A. 2008. Fingerprinting ash deposits of small scale eruptions by their physical and textural features. Journal of Volcanology and Geothermal Research 177 (1): 277-287.

Cioni, R.; Pistolesi, M.; Bertagnini, A.; Bonadonna, C.; Hoskuldsson, A.; Scateni, B. 2014. Insights into the dynamics and evolution of the 2010 Eyjafjallajökull summit eruption (Iceland) provided by volcanic ash textures. Earth and Planetary Science Letters 394: 111-123.

Clarke, A.B.; Ongaro, T.E.; Belousov, A.; 2015. Vulcanian eruptions. In The Encyclopedia of Volcanoes (Sigurdsson, H.; Houghton, B.; McNutt, S.; Rymer, H.; Stix, J.; editors). Elsevier: 1456 p.

Dellino, P.; Kyriakopoulos, K. 2003. Phreatomagmatic ash from the ongoing eruption of Etna reaching the Greek island of Cefalonia. Journal of Volcanology and Geothermal Research 126: 341-345.

Dellino, P.; La Volpe, L. 1995. Fragmentation versus transportation mechanisms in the pyroclastic sequence of Monte Pilato-Rocche Rosse (Lipari, Italy). Journal of Volcanology and Geothermal Research 64: 211-232.

Díaz-Alvarado, J.; Castro, A.; Fernández, C.; Moreno-Ventas, I. 2011. Assessing bulk assimilation in cordierite-bearing granitoids from the Central System batholith, Spain; experimental, geochemical and geochronological constraints. Journal of Petrology 52, 223-256.

Douillet, G.A.; Pacheco, D.A.; Kueppers, U.; Letort, J.; Tsang-Hin-Sun, Ė.; Bustillos, J.; Hall, M.; Ramón, P.; Dingwell, D.B. 2013a. Dune bedforms produced by dilute pyroclastic density currents from the August 2006 eruption of Tungurahua volcano, Ecuador. Bulletin of Volcanology 75: 762 p. doi:10.1007/s00445-013-0762-x.

Douillet, G.A.; Tsang-Hin-Sun, E.; Kueppers, U.; Letort, J.; Pacheco, D.A.; Goldstein, F.; Von Aulock, F.; Lavallée, Y.; Hanson, J.B.; Bustillos, J.; Robin, C.; Ramón, P.; Hall, M.; Dingwel, D.B. 2013b. Sedimentology and geomorphology of the deposits from the August 2006 pyroclastic density currents at Tungurahua volcano, Ecuador. Bulletin of Volcanology 75: 765 p. doi: 10.1007/s00445-013-0765-7.

Durant, A.J.; Rose, W.I.; Sarna-Wojcicki, A.M.; Carey, S.; Volentik, A.C.M. 2009. Hydrometeor-enhanced tephra sedimentation: constraints from the 18 May, 1980 eruption of Mount St. Helens. Journal of Geophysical Research 114: B03204.

Eychenne, J.; Le Pennec, J-L.; Troncoso, L.; Gouhier, M.; Nedelec, J.M. 2012. Causes and consequences of bimodal grain-size distribution of tephra fall deposited during the August 2006 Tungurahua eruption (Ecuador). Bulletin of Volcanology 74: 187-205.

Eychenne, J.; Le Pennec, J-L.; Ramón, P.; Yepes, H. 2013. Dynamics of explosive paroxysms at open-vent andesitic systems: High resolution mass distribution analyses of the 2006 Tungurahua fall deposit (Ecuador). Earth and Planetary Science Letters 361: 343-355.

Fee, D.; Garcés, M.; Steffke, A. 2010. Infrasound from Tungurahua Volcano 2006-2008: Strombolian to Plinian activity. Journal of Volcanology and Geothermal Research 193: 67-81.

Fierstein, J.; Houghton, B.F.; Wilson, C.J.N.; Hildreth, W. 1997. Complexities of plinian fall deposition at vent: an example from the 1912 Novarupta eruption(Alaska). Journal of Volcanology and Geothermal Research 76: 215-227.

Folk, R.L.; Ward, W.C. 1957. Brazos river bar: A study in the significance of grain size parameters. Journal of Sedimentary Petrology 27: 3-26.

Gaunt, H.E.; Bernard, B.; Hidalgo, S.; Proaño, A.; Wright, H.; Mothes, P.; Criollo, E.; Kueppers, U. 2016. Juvenile 
magma recognition and eruptive dynamics inferred from the analysis of ash time series: The 2015 reawakening of Cotopaxi volcano. Journal of Volcanology and Geothermal Research 328: 134-146.

Goodyear, J.; Duffin, W.J. 1954. The identification and determination of plagioclase feldspars by the X-ray powder method. Mineralogical Magazine 30: 306-326.

Gudmundsson, G. 2011. Respiratory health effects of volcanic ash with special reference to Iceland. A review. The Clinical Respiratory Journal 5 (1): 2-9.

Hall, M.; Robin, C.; Beate, B.; Mothes, P.; Monzier, M. 1999. Tungurahua Volcan, Ecuador: structure eruptive history and hazards. Journal of Volcanology and Geothermal Research 91: 1-21.

Hall, M.L.; Samaniego, P.; Le Pennec, J-L.; Johnson, J.B. 2008. Ecuadorian Andes volcanism: A review of Late Pliocene to present activity. Journal of Volcanology and Geothermal Research 176 (1): 1-6.

Hall, M.; Steele, A.L.; Mothes, P.A.; Ruiz, M.C. 2013. Pyroclastic density currents (PDC) of the 16-17 August 2006 eruptions of Tungurahua volcano, Ecuador: Geophysical registry and characteristics. Journal of Volcanology and Geothermal Research 265: 78-93.

Hall, M.L.; Steele, A.; Bernard, B.; Mothes, P.; Vallejo, S.; Doulliet, G.A.; Ramón, P.; Aguaiza, S.; Ruiz, M. 2015. Sequential plug formation, desintegration by vulcanian explosions, and the generation of granular pyroclastic density currents at Tungurahua volcano (2013-2014), Ecuador. Journal of Volcanology and Geothermal Research 306: 90-103. doi: 10.1016/j. jvolgeores.2015.09.009.

Heiken, G.; Wohletz, K.H. 1985. Volcanic Ash. University of California Press: 245 p. Berkeley.

Hidalgo, S.; Battaglia, J.; Arellano, S.; Steele, A.; Bernard, B.; Bourquin, J.; Galle, B.; Arrais, S.; Vásconez, F. 2015. $\mathrm{SO}_{2}$ degassing at Tungurahua volcano (Ecuador) between 2007 and 2013: transition from continuous to episodic activity. Journal of Volcanology and Geothermal Research 298: 1-14.

Horwell, C.J.; Baxter, P.J. 2006. The respiratory health hazards of volcanic ash: a review for volcanic risk mitigation. Bulletin of Volcanology 69 (1): 1-24. doi: 10.1007/s00445-006-0052-y.

Houghton, B.F.; Carey, R.J. 2015. Pyroclastic Fall Deposits. In The Encyclopedia of Volcanoes (Sigurdsson, H.; Houghton, B.; McNutt, S.; Rymer, H.; Stix, J.; editors). Elsevier: 1456 p.

Houghton, B.F.; Smith, R.T. 1993. Recycling of magmatic clasts during explosive eruptions: estimating the true juvenile content of phreatomagmatic volcanic deposits. Bulletin of Volcanology 55 (6): 414-420.

Houghton, B.F.; Wilson, C.J.N.; Fierstein, J.; Hildreth, W. 2004. Complex proximal deposition during the Plinian eruptions of 1912 at Novarupta, Alaska. Bulletin of Volcanology 66: 95-133.

Inguaggiato, S.; Hidalgo, S.; Beate, B.; Bourquin, J. 2010. Geochemical and isotopic characterization of volcanic and geothermal fluids discharged from the Ecuadorian volcanic arc. Geofluids 10 (4): 525-541.

Jones, R.; Manville, V.; Andrade, D. 2015. Probabilistic analysis of rain-triggered lahar initiation at Tungurahua volcano. Bulletin of Volcanology 77 (8): 68 p.

Kley, J.; Monaldi, C.; Salfity, J. 1999. Along-strike segmentation of the Andean foreland; causes and consequences. Tectonophysics 301: 75 -94.

Kim, K.; Lees, J. M.; Ruiz, M.C. 2014. Source mechanism of Vulcanian eruption at Tungurahua Volcano, Ecuador, derived from seismic moment tensor inversions. Journal of Geophysical Research: Solid Earth 119: 1145-1164.

Lautze, N.; Taddeucci, J.; Andronico, D.; Cannata, Ch.; Tornetta, L.; Scarlato, P.; Houghton, B.; Lo Castro, M. 2012. SEM-based methods for the analysis of basaltic ash from weak explosive activity at Etna in 2006 and the 2007 eruptive crisis at Stromboli. Physics and Chemistry of the Earth (A) 45-46: 113-127.

Le Maitre, R.W. 1984. A proposal by the IUGS Subcommission on the Systematics of Igneous Rocks for a chemical classification of volcanic rocks based on the total alkali silica (TAS) diagram: (on behalf of the IUGS Subcommission on the Systematics of Igneous Rocks). Australian Journal of Earth Sciences 31 (2): 243-255.

Le Pennec, J-L.; Mothes, P.; Ramón, P.; Ruiz, G. 2002. Maximum and minimum volume estimates of an ash fall layer from the august 2001 eruption of Mt Tungurahua (Ecuador). In International Society for Animal Genetics: ISAG, No. 5, Extended Abstract: 371-374. Toulouse, France.

Le Pennec, J.-L.; Ruiz, A.G.; Mothes, P.; Hall, M.; Alvarado, A.; García, A.; Segovia, M. 2004. Estimación del volumen del depósito de ceniza de la erupción de Agosto 2001 del Volcán Tungurahua: Investigaciones en Geociencias 1: 13-18.

Le Pennec, J-L.; Hall, M.; Robin, C.; Bartomioli, E. 2006. Tungurahua Volcano, Late Holocene Activity. Field Guide, Cities on Volcanoes, No. 4: 24 p. Quito.

Le Pennec, J-L.; Jaya, D.; Samaniego, P.; Ramón, P.; MorenoYánez, S.; Egred, J.; Van Der Plicht, J. 2008. The AD 1300-1700 eruptive periods at Tungurahua volcano, 
Ecuador, revealed by historical narrative, stratigraphy and radiocarbon dating. Journal of Volcanology and Geothermal Research 176: 70-81.

Le Pennec, J.L.; Ruiz, G.A.; Ramón, P.; Palacios, E.; Mothes, P.; Yepes, H. 2012. Impact of tephra falls on Andean communities: the influences of eruption size and weather conditions during the 1999-2001 activity of Tungurahua volcano, Ecuador. Journal of Volcanology and Geothermal Research 217: 91-103.

Litherland, M.; Egüez, A. 1993. Mapa Geológico de la República del Ecuador 1:1,000,000. British Geological Survey (Keyworth, Nottingham) and CODIGEM, Quito, Ecuador.

Molina, I.; Kumagai, H.; Le Pennec, J-L.; Hall, M. 2005. Three-dimensional P-Wave velocity structure of Tungurahua volcano, Ecuador. Journal of Volcanology and Geothermal Research 147: 144-156.

Morrissey, M.; Mastin, L.G. 2000. Vulcanian eruptions. In Encyclopedia of Volcanoes (Sigurdsson, H.; Houghton, B.; Rymer, H.; Stix, J.; McNutt, S.; editors). Academic Press: 1417.

Mothes, P.; Yepes, H.A.; Hall, M.L.; Ramón, P.A.; Steele, A.L.; Ruiz, M. 2015. The scientific-community interface over the fifteen years eruptive episode of Tungurahua Volcano, Ecuador. Journal of Applied Volcanology 4: 9 p.

Moune, S.; Faure, F.; Gauthier, P.J.; Sims, K.W. 2007. Pele's hairs and tears: natural probe of volcanic plume. Journal of Volcanology and Geothermal Research 164 (4): 244-253.

Myers, M.L.; Geist, D.J.; Rowe, M.C.; Harpp, K.S.; Wallace, P.J.; Dufeck, J. 2014. Replenishment of volatile-rich mafic magma into a degassed chamber drives mixing and eruption of Tungurahua volcano. Bulletin of Volcanology 76: p. 872. doi: 10.1007/ s00445-014-0872-0.

Paladines, J.L.; Zamora, C.P. 2011. Impacto provocado por el volcán Tungurahua en la salud de los pobladores de Penipe durante el período eruptivo comprendido entre el año 2003-2010. Tesis (Inédito). Pontificia Universidad Católica del Ecuador: 134 p.

Parra, R.; Bernard, B.; Narváez, D.; Le Pennec, J-L.; Hasselle, N.; Folch, A. 2015. Eruption Source Parameters for forecasting ash dispersion and deposition from vulcanian eruptions at Tungurahua volcano: Insights from field data from the July 2013 eruption.Journal of Volcanology and Geothermal Research 309: 1-13. doi: 10.1016/j.jvolgeores.2015.11. 001.
Polacci, M. 2005. Constraining the dynamics of volcanic eruptions by characterization of pumice textures. Annals of Geophysics 48 (4-5): 731-738.

Rollenbeck, R.; Bendix, J. 2011. Rainfall distribution in the Andes of southern Ecuador derived from blending weather radar data and meteorological field observations. Atmospheric Research 99 (2): 277-289.

Romero, J.E.; Douillet, G.A.; Vargas, S.V.; Bustillos, J.; Troncoso, L.; Alvarado, J.D.; Ramón, P. 2017. Dynamics and style transition of a moderate, Vulcanian-driven eruption at Tungurahua (Ecuador) in February 2014: pyroclastic deposits and hazard considerations. Solid Earth 8 (3): 697 p.

Ruiz, G.; Barba D.; Yepes, H.; Hall, M. 2004. Las Nubes de Ceniza del Volcán Tungurahua entre Octubre de 1999 y Septiembre de 2001. Investigaciones en Geociencias, Instituto Geofísico, Escuela Politécnica Nacional 1: 28-34.

Ruiz, A.; Le Pennec, J.-L.; Palacios, E.; Hall, M.; Yepes, H. 2006. Indirect estimation of ash fall volume deposited near Tungurahua volcano (Ecuador) from Oct. 1999 to Dec. 2004. Cities on Volcanoes IAVCEI, No. 4: p. 27. Quito.

Samaniego, P.; LePennec, J-L.; Robin, C.; Hidaldo, S. 2011. Petrological analysis of the pre-eruptive magmatic process prior to the 2006 explosive eruptions at Tungurahua volcano (Ecuador). Journal of Volcanology and Geothermal Research 199: 69-84.

Scasso, R.A.; Corbella, H.; Tiberi, P. 1994. Sedimentological analysis of the tephra from the 12-15 August 1991 eruption of Hudson volcano. Bulletin of Volcanology 56: 121-132.

Sheridan, M.F.; Marshall, J.R. 1983. Interpretation of Pyroclast Surface Features Using SEM Images. Journal of Volcanology and Geothermal Research 16: 153-159.

Steffke, A.; Fee, D.; Garces, M.; Harris, A. 2010. Eruption chronologies, plume heights and eruption styles at Tungurahua volcano: Integrating remote sensing techniques and infrasound. Journal of Volcanology and Geothermal Research 193: 143-160.

Stern, C.R. 2004. Active Andean volcanism: its geologic and tectonic setting. Revista Geológica de Chile 31 (2): 161-206. doi: 10.5027/andgeoV31n2-a01.

Stone, J.; Barclay, J.; Simmons, P.; De Cole, P.; Loughlin, S.; Ramón, P.; Mothes, P. 2014. Risk reduction through community-based monitoring: the vigías of Tungurahua, Ecuador. Journal of Applied Volcanology 3: $11 \mathrm{p}$.

Taddeucci, J.; Edmonds, M.; Houghton, B.; James, M.R.; Vergniolle, S. 2015. Hawaiian and Strombolian eruptions. In The encyclopedia of volcanoes 
(Sigurdsson, H.; Houghton, B.; McNutt, S.; Rymer, H.; Stix, J.; editors). Elsevier: 1456 p.

Troncoso, L.; Le Pennec, J-L.; Jaya, D.; Vallee A.; Mothes, P.; Arrais, S. 2006. Depósitos de caída de ceniza producidos durante las erupciones del volcán Tungurahua, 14 de julio y 16 de agosto de 2006. In Jornadas en Ciencias de la Tierra, No. 6. Escuela Politécnica Nacional, Departamento de Geología: 181-184. Quito.

Troncoso, L.; Bustillos, J.; Romero, J.E.; Guevara, A.; Carrillo, J.; Montalvo, E.; Izquierdo, T. 2017. Hydrovolcanic ash emission between August 14 and 24, 2015 at Cotopaxi volcano (Ecuador): Characterization and eruption mechanisms. Journal of Volcanology and Geothermal Research 341: 228-241.
Tsunematsu, K.; Bonadonna, C. 2015. Grain-size features of two large eruptions from Cotopaxi volcano (Ecuador) and implications for the calculation of the total grain-size distribution. Bulletin of Volcanology 77:64.

Walker, G.P.L. 1971. Grain-size characteristics of pyroclastic deposits. The Journal of Geology 79: 619-714.

Wohletz, K.H. 1986. Explosive magma-water interactions: Thermodynamics, explosion mechanisms, and field studies. Bulletin of Volcanology 48 (5): 245-264.

Wright, H.; Cashman, K.; Mothes, P.; Hall, M.; Ruiz, A.; Le Pennec, J.-L. 2012. Estimating rates of decompression from textures of erupted ash particles produced by 1999-2006 eruptions of Tungurahua volcano, Ecuador. Geology 40: 619-622.

Manuscript received: February 5, 2017; revised/accepted: October 17, 2017; available online: October 17, 2017. 